INTERNATIONAL MONETARY FUND

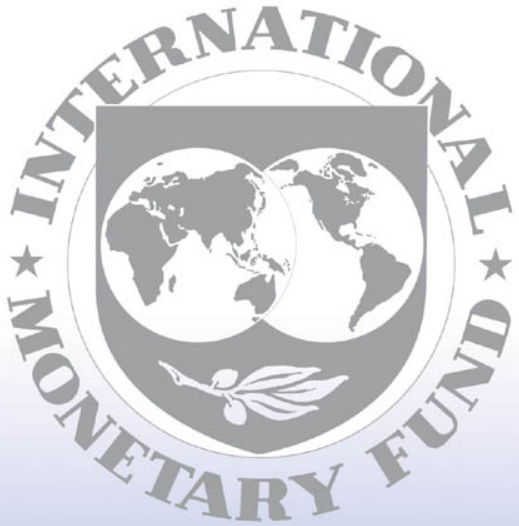

Staff

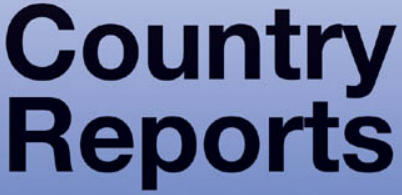




\section{Belgium: Report on Observance of Standards and Codes- Fiscal Transparency Module}

This Report on the Observance of Standards and Codes on Fiscal Transparency for Belgium was prepared by a staff team of the International Monetary Fund as background documentation for the periodic consultation with the member country. It is based on the information available at the time it was completed on March 17, 2008. The views expressed in this document are those of the staff team and do not necessarily reflect the views of the government of Belgium or the Executive Board of the IMF.

The policy of publication of staff reports and other documents by the IMF allows for the deletion of market-sensitive information.

Copies of this report are available to the public from

International Monetary Fund $\bullet$ Publication Services

700 19th Street, N.W. • Washington, D.C. 20431

Telephone: (202) $6237430 \bullet$ Telefax: (202) 6237201

E-mail: publications@imf.org • Internet: http://www.imf.org

Price: $\$ 18.00$ a copy

\section{International Monetary Fund \\ Washington, D.C.}


This page intentionally left blank

CInternational Monetary Fund. Not for Redistribution 
INTERNATIONAL MONETARY FUND

\title{
BELGIUM
}

\section{Report on the Observance of Standards and Codes (ROSC) Fiscal Transparency Module}

\author{
Prepared by the Fiscal Affairs Department
}

Approved by Michael Deppler and Teresa Ter-Minassian

March 17, 2008

\section{EXECUTIVE SUMMARY}

Belgium in many areas meets, and in some cases exceeds, the requirements of the fiscal transparency code. The basic government finance processes are supported by a sound institutional and legal framework. Roles and responsibilities in the budget process are clear, with a well-defined separation of powers between the executive and legislature. Fiscal information is provided through regular publications and extensive use of the internet. Budget formulation is appropriately supported by medium-term macroeconomic forecasts and clearly formulated medium-term fiscal policy goals, and fiscal policy is presented clearly, and in a medium-term context. Finally, audit processes are extensive and help improve budget management decisions, practices and standards, with government financial decisions evaluated ex ante and ex post by various institutions.

There is room to improve the quality and openness of budget processes: (i) there is limited insight about the objectives and targets of government expenditure; (ii) the medium-term budget estimates need to make budgetary decision-making more oriented to the medium-term; (iii) the presentation of new policy measures and their medium-term costs could be clarified; (iv) and budget implementation by departments and agencies could be streamlined.

Information available to the public on the following topics could be increased: (i) fiscal risk and tax expenditures in budget documents; (ii) in-year budgetary data on local government and agencies; (iii) the content of the final government accounts; and (iv) the governance of state-owned equity holdings.

Institutional arrangements for fiscal policy coordination could be strengthened by (i) reinforcing and expanding the role of the High Council of Finance, including by providing additional institutional safeguards as to its continuity and independence, and having the Council cover all important issues bearing on fiscal policy; and (ii) converting the budget agreements between the federal government, regions, and communities into published agreements which specify the targeted balance for each partner and identify the measures needed to achieve this target.

Finally, internal audit processes could be better coordinated and simplified by reducing the number of internal control and audit layers - which makes the Court of Audit's recent Single Audit initiative to minimize overlap, coordinate work programs, and to share common data and analysis, particularly timely. 
Abbreviations

I. Detailed Description Of Practice . .4

A. Clarity of Roles and Responsibilities.....

B. Open Budget Preparation, Execution, and Reporting …............................. 16

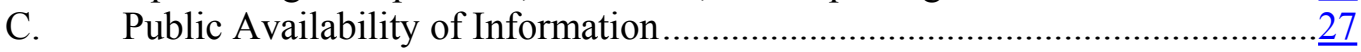

D. Assurances of Integrity ..................................................................

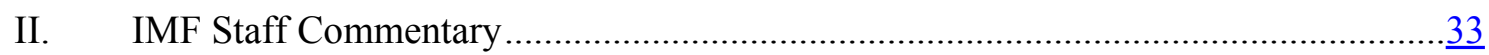

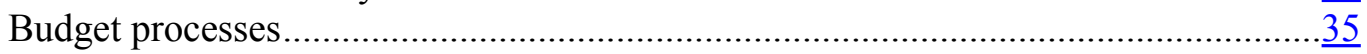

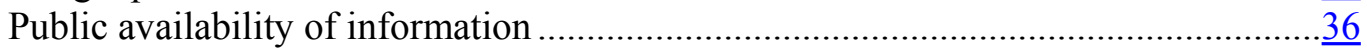

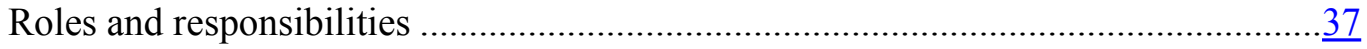

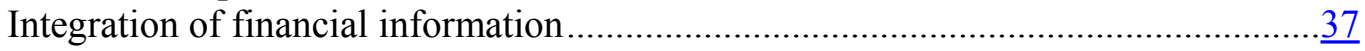

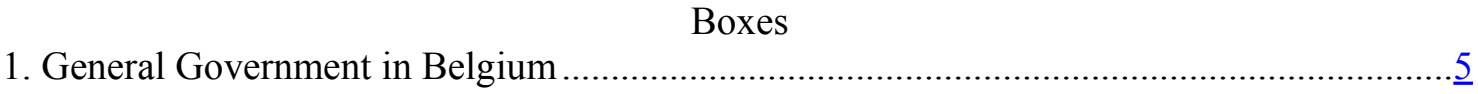

2. The Management of Government Equity Holdings ..................................................... $\underline{6}$

3. The 1991 Public Economic Enterprise Law .................................................................. $\frac{8}{8}$

4. The High Council of Finance................................................................................... $\frac{12}{17}$

5. The Budget Preparation Process ….................................................................... $\frac{17}{18}$

6. The Medium-Term Budgetary Framework................................................................18

Appendixes

I. A Summary Assessment of Practices ................................................................... $\frac{39}{42}$

II. Public Availability of Information-A Summary …............................................... 


\section{ABBREVIATIONS}

GFS

ROSC

SDDS

OFOG

$\mathrm{EBF}$

EMU

ECB

ESA95

ESCB

EU

FPIC

GDP

GFS

GFSM1986/2001

HFC

IMF

NAI

NBBN

NMBS/SNCB

MTBF

OECD

OLAF

PPP

VAT
Government Finance Statistics

Report on the Observance of Standards and Codes

Special Data Dissemination Standard

Classification of the Functions of Government

Extra-budgetary Fund

European Monetary Union

European Central Bank

European System of Accounts, 1995

European System of Central Banks

European Union

Federal Participation and Investment Company

Gross Domestic Product

Government Finance Statistics

Government Finance Statistics Manual 1986, or 2001, respectively

High Finance Council

International Monetary Fund

National Accounts Institute

Nationale Bank/Banque Nationale (the Belgian central bank)

Nationale Maatschappij der Belgische Spoorwegen/ Société Nationale des Chemins de Fer Belges (the Belgian National Railways Company) Medium-Term Budgetary Framework

Organization for Economic Cooperation and Development

Office Européen de Lutte Anti-Fraude (European Anti-Fraud Office)

Public Private Partnership

Value Added Tax 


\section{Detailed Description Of Practice ${ }^{12}$}

\section{A. Clarity of Roles and Responsibilities}

\section{Definition of government activities}

1. General government is defined consistently with Government Finance Statistics (GFS) principles, and is well covered in the budget process at an aggregate level.

The four main general government sectors, as presented in Box 1, are defined with reference to the European System of Accounts 1995 (ESA 95), which reflects the same basic principles as GFS. ${ }^{3}$ A number of consecutive revisions of the Belgian Constitution during 1970-2001 have created a new level of government - comprising communities and regions - and transformed Belgium into a federal state. For the purposes of fiscal analysis, the combined federal government and social security system constitute the socalled Entity I, and the communities, regions and local authorities constitute Entity II.

\section{The federal government, communities and regions have delegated the} provision of public services to a large extent to agencies and institutions with varying degrees of administrative and operational autonomy. $1.1 .1,1.1 .3$ These are separate legal entities with their own charter and their own budget and accounts; they generally receive part or most of their funding from the delegating authority and are subject to administrative and financial controls. Prominent among the autonomous agencies and institutions are the social parastatals which administer the finances of the social security system and account for around 40 percent of general government spending. Their operation and management are governed by special legislation, which provides for the conclusion of management contracts with the federal government. Commercial activities undertaken by general government are of limited scope and importance in Belgium.

\section{Relationships between government and public nonfinancial and financial corporations are clearly defined, but reporting on government holdings in corporations is not very transparent.

General government is clearly separated from public sector corporations operating in both the financial and non-financial sectors. In the wake of the privatization of two major and a number of smaller government-owned financial institutions in the 1990s,

\footnotetext{
${ }^{1}$ Discussions on fiscal transparency were held in Brussels during February 14-27, 2007. The mission, comprising Messrs. J. Thornton (Head), M. De Broeck, H. van Eden, and P. B. Spahn, met with officials from the federal Ministries of Finance and the Budget, the National Bank of Belgium, the Federal Planning Bureau, the Court of Audit, the Finance and Budget Ministries of the regions and communities, and the main social security institutions. Staff also met with former prime minister Jean-Luc Dehaene, and with representatives of the main state-owned enterprises, employers organizations, and the academic community. The mission is very grateful for the exemplary efforts made by the Ministry of Finance's Treasury to organize and support its work and for warm hospitality it received from its many interlocutors.

${ }^{2}$ The reference for the assessment is the 2001 version of the fiscal transparency code.

${ }^{3}$ A detailed description of these four sectors is provided on the website of the Belgian National Bank (http://www.bnb.be).
} 


\begin{tabular}{|l|l|}
\hline \multicolumn{2}{|c|}{ Box 1. General Government in Belgium } \\
\hline General government in Belgium comprises the following : & $\begin{array}{l}\text { Percent of GDP. } \\
2006\end{array}$ \\
\hline Federal government & 11.6 \\
\hline Social security institutions & 19.1 \\
\hline Communities and regions & 11.5 \\
\hline Local Government & 6.9 \\
\hline 589 provinces & \\
\hline
\end{tabular}

government involvement in the financial sector has been scaled down considerably and is now limited to some specialized institutions involved in the financing of social housing and the provision of export insurance, and a small number of governmentowned holding companies. The latter include the Federal Participation and Investment Company (see Box 2) and, most importantly, a number of holding companies owned by the regions that support regional industrial policy initiatives.

\section{Government relations with nonfinancial public corporations and the private sector}

\section{Government equity holdings in non-financial enterprises are wide-ranging.}

\section{$1.1 .4,1.1 .5$}

The federal government continues to have a majority participation in three major nonfinancial enterprises that operate as limited liability companies under public law and are expected to pay dividends to shareholders. The federal government also fully owns the National Lottery, which has to pay a monopoly rent and allocate its profits to cultural, social and development aid programs according to a royal decree-based formula. Both the federal government and the regions are minority-shareholders in a range of nonfinancial companies operating under private law. In addition to being a minorityshareholder, the federal government owns a controlling share ("golden share") in selected private companies, notably the country's main gas supplier (Distrigaz) and its main gas distribution company (Fluxys). Selected government shares in non-financial enterprises are held and managed by the Federal Participation and Investment Company and the regional holding companies. Including the local level, government has an equity holding of 5 percent or more in around 3,000 companies, which together employ around 9 percent of the labor force and account for about 10 percent of GDP. After the major privatizations in the 1990s, there are no plans for further large-scale privatization and no overall strategy as to what the government aims to achieve with its present equity holdings. 


\section{Box 2. The Management of Government Equity Holdings ${ }^{4}$}

Government equity participation in the enterprise sector continues to be important in Belgium, but there is no centralisation of the ownership function or aggregate reporting. It is estimated that the federal government owns financial participations in more than 250 enterprises, more than half of which are majority participations. A State Secretary oversees the management of the largest of these enterprises, and annually reports to Parliament on their performance and outlook in the context of the budget preparation process. In addition, a government-owned holding company, the Federal Participation and Investment Company (FPIC), holds - and reports on - share packages in a number of enterprises selected by the federal government as requiring special assistance or monitoring. But for the most part, government shares are held and managed by individual ministers and agencies, and information on them is available on an enterprise-by-enterprise basis only.

The FPIC owns a minority share package in two of the four largest state-owned enterprises, the National Lottery and the Postal company, but is not directly involved in their management. The FPIC is also shareholder (in both majority and minority positions) in about a dozen other state-owned companies and in a number of private companies. In some cases, the participations have been taken for the FPIC's own account. The establishing law does not set out the goals of the government's equity participations or the strategy towards investing in these companies. The holding is currently developing its own strategy for investing in companies and managing share holdings, and envisages taking on a more important role in the overall management of federal government equity participations.

The FPIC also is mandated to promote federal government economic initiatives in general and can be tasked with special economic assignments on the government's behalf. Such assignments have to be specified by law or royal decree, and the corresponding activities are funded by the federal government and separately reported in the FPIC's accounts. Assignments on behalf of the federal government typically are a matter of investing in selected companies in the social and industrial sectors that either are in a start-up phase or are having financial difficulties, but more recently also have involved organizing the sale of shares in a real investment trust owned by the federal government. Any debt taken on by the FPIC for activities that support the federal government's economic policies is fully covered by a government guarantee, and such debt is separately reported in its accounts and at the same time included in the federal government debt. ${ }^{5}$

Under OECD best practice, the management of government equity holding would usually be centralized in a specialized and independent holding and management company. The goals and activities of such a company would be defined by a legal framework and brought at armslength of day-to-day government activities.

\section{The 1991 public economic enterprise law has created a special governance framework for the major non-financial enterprises that are majority-owned by the federal government (Box 3).}

These enterprises operate under management contracts that typically give an appointed management team a large degree of operational and strategic autonomy to meet agreed service targets, and which also regulate profit transfers to the budget. The most

\footnotetext{
${ }^{4}$ Apart from the federal institutions, there also are regional holding companies, such as Participatiemaatschappij Vlaanderen and Société Wallone de Gestion et de Participations.

${ }^{5}$ Sven Boullart en Luc Depré, "De relatie tussen schulden van instellingen van openbaar nut en de overheidsschuld. Europees en federaal Belgisch perspectief," Chroniques de Droit PublicPubliekrechtelijke Kronieken," 2005, pp. 4-23.
} 
important of the autonomous public enterprises are the former state monopolies in the network industries - Belgacom (telecommunications) and De Post/La Poste, which were partially privatized in the 1990s, and where the government retains 50 percent plus 1 of the shares - and the national railway company NMBS/SNCB, of which the government remains the dominant shareholder. The management contracts for these three companies specify their service obligations, the financial implications of which have to be separately accounted for and reported. While major progress has been made in costing and reporting service activities undertaken on behalf of the government, opportunity costs for the government related to below-market returns on its equity position are not clearly presented in budget documents. In line with acquis communautaire requirements, market access to network industries has been liberalized, and independent regulatory bodies set up. In the railway sector, network management and transport operations have been separated, but both activities continue to be tightly controlled by the federal government through a holding company arrangement.

\section{Government equity participations are not clearly reported.}

The main sources of information are the annual reports of the various governmentowned holding companies, the annual report of the Federal Participation and Investment Company and one-off research reports prepared by the Planning Bureau. ${ }^{6}$ There is no systematic reporting on government equity holdings in the budget documentation.

\section{Laws and processes governing government regulation of the nonfinancial private sector are overall clear and open.}

Regulation of private sector activities in Belgium is aimed at ensuring a smooth functioning of the market, and is mainly contained in rules on business establishments, competition, product standards, price regulation and trade practices. Many regulations have been adapted to conform with the acquis communautaire, a good example of which are the EU directives aimed at safeguarding competition within the single market. The regulations governing private sector activities are clearly and extensively documented on the website of the Ministry of the Economy, Small- and Medium-size Enterprises, Self-employed and Energy.

\footnotetext{
${ }^{6}$ H. Spinnewijn, "Overheidsparticipaties in de markt sector in Belgie, 1997-2003," Planning Paper No. 99, Brussels: Federal Planning Bureau, 2006. Available at http://www.plan.be.
} 


\section{Box 3. The 1991 Public Economic Enterprise Law}

The Law of March 21, 1991 on the reform of some state-owned enterprises introduced a new framework for the exercise of state ownership functions. It puts in place a management contract arrangement that establishes an arms-length relationship between the supervisory ministry or agency and the enterprise in question. The contract typically spells out the broad policy objectives for the enterprise, specifies its public and universal service obligations, grants it a large degree of managerial and operational autonomy, and defines the financial aspects and enforcement mechanisms of the contractual relationship. The Law also introduces a two-tier governance structure for state-owned enterprises - a combination of a board of directors with a number of specialized subcommittees and a management committee - and establishes a monitoring arrangement on behalf of the government. A representative of the supervising minister or agency participates in the board of directors and management committee meetings to monitor compliance with the law and the management contract, and can appeal against their decisions. The Law moreover requires separate accounting and reporting for activities related to public and universal service obligations and the corresponding compensation from the government, and it establishes a dual external auditing regime - a combination of standard auditing under general commercial law principles and special auditing by two representatives of the Court of Audit.

However, the scope of the 1991 law has remained limited. The law only applies to three large state-owned enterprises identified in the law itself. Moreover, the initial measure of uniformity introduced in the Law has been fragmented by subsequent laws, which have tailored its principles to the specific conditions of each of the three enterprises. The telecommunications company, Belgacom, is stock exchange-listed and has a corporate governance structure that reflects the important involvement of private shareholders-Belgacom shares other than those owned by the federal government (the majority shareholder) are free floating. Belgacom is a profitable company and regularly pays dividends, while operating in a fully liberalised and competitive market. The postal services company, De Post/La Poste, is unlisted and has only one private shareholder, which owns 50 percent minus one of the shares. An agreement between this shareholder and the two public shareholders - the federal government and the FPIC - specifies how control over the company is shared. The Post/La Poste is currently profitable, but its financial results in part reflect the company's maintained monopoly in the small letter postal market segment. Finally, the national railway company, NMBS/SNCB, is a 100 percent state-owned group, but its governance has been complicated by EU requirements on the liberalization of rail transport and large financing needs. A holding company has been set up with two daughter companies, an infrastructure manager and a railway operator, and a special ownership structure has been created to safeguard the independence of the former. Large government subsidies, which amount to around 0.8 percent of GDP and in part are aimed at financing infrastructure investment, allow the NMBS/SNCB group to broadly break even.

\section{Measures introduced in recent years to reduce the administrative burden of doing business appear to have had some success.

A single identification number for business activities has been introduced, and efforts have been made to set e-government service standards and organize information exchange between various government agencies and levels through common databases. In addition, a federal agency for administrative simplification has been created; a program to systematically identify and reduce burdensome regulations on 
the basis of information provided by entrepreneurs and individuals has been established; and there is a web-based tax filing and payment system. Similar efforts to promote administrative simplification and e-government are pursued in communities and regions. ${ }^{7}$ According to the World Bank's most recent "Doing Business" report, Belgium ranks in the middle range of OECD countries with respect to the regulatory burden facing business. ${ }^{8}$ Areas of relative strength include the number of procedural steps needed to start a business; the number of payments and time spent preparing, filing and paying taxes (which could reflect the recent efforts to roll out electronic filing and payment), and the arrangements for resolving bankruptcies. On the other hand, obtaining licenses and utility connections and registering property are more burdensome in Belgium than is the average for OECD countries. Time spent starting a business also exceeds the OECD average, but the "Doing Business" indicator shows an improvement in recent years, probably reflecting the efforts to simplify the registration of new enterprises through a "one-stop shop" arrangement.

\section{The government-related administrative costs facing businesses in Belgium} also appear to have declined.

Estimates of the administrative costs facing incorporated enterprises and the selfemployed can be found in bi-annual reports published by the Federal Planning Bureau. ${ }^{9}$ According to the most recent estimates, based on 2004 survey data, costs related to environmental, employment and tax regulations amount to 1.7 percent and 0.8 percent of GDP, respectively, the largest component of which is related to compliance with tax regulations. A comparison with earlier surveys suggests that administrative costs have declined since 2000 , notably in the fiscal area, and that both enterprises and self-employed regard the single identification number and the systematic exchange of information between government agencies and levels as particularly noteworthy improvements.

\section{Government relations with the central bank and public financial sector}

\section{The Nationale Bank/Banque Nationale (NBBN) has only an advisory role in} fiscal matters.

Belgium is a European Monetary Union (EMU) member, and its central bank participates in the European System of Central Banks (ESCB) in setting monetary policy for the Euro area. Its independence from government in these matters is safeguarded under the acquis communautaire and enshrined in the 1998 central bank law. In addition to its EMU-related activities, the NBBN carries out a range of domestic activities under the 1998 law. This law also specifies the arrangements for profit transfers to the government on account of its ownership of 50 percent of NBBN shares. ${ }^{10}$ The NBBN is the fiscal agent of government and in this capacity it centralizes

\footnotetext{
${ }^{7}$ Suggestions for administrative simplifications can be submitted to the website of the agency, http://www.kafka.be.

${ }^{8}$ The most recent "Doing Business" was released in fall 2007 and can be found at http://www.doingbusiness.org.

${ }^{9}$ Janssen, L., C. Kegels, and F. Verschueren, 'Les charges administratives on Belgigue pour l'année 2004," Planning Paper No. 100, Brussels: Federal Planning Bureau, 2006, available at http://www.plan.be.

${ }^{10}$ The other 50 percent are listed on Euronext's Eurolist and held by private investors.
} 
all cash transactions carried out on behalf of the federal government in a single Treasury account (payment transactions themselves are carried out through the financial branch of the Postal Company). The NBBN is also in charge of the issuance and financial service of government bonds in paper format, and responsible for the daily management of the Securities Regulation Fund, which performs various functions relating to the operation of the secondary market in government debt securities. Finally, NBBN staff supports the work of the borrowing requirements section of the High Finance Council. The NBBN is not remunerated for the provision of these various services.

\section{Fiscal management relations among the branches of government}

\section{The fiscal roles of the executive, legislative and judicial branches are clearly defined in the Constitution and law.

At all levels of government, the executive branch is responsible for budget preparation and execution. Budgets and final accounts have to be approved by the assemblies elected for the corresponding level of government. At the federal level, two assemblies are elected, the House of Representatives and the Senate, but only the House has budgetary powers. In carrying out these tasks, the federal, community and regional assemblies are assisted by an independent Court of Audit. The third branch of government, the judiciary, is a federal institution, and it settles disputes with tax payers, government contractors, and recipients of social benefits and grants, and can be called upon to sanction unlawful behavior of civil servants.

\section{Fiscal management relations among different levels of government}

12. The responsibilities of different levels of government are clearly defined. 1.1 .2 Revisions to the Constitution in 1993 and 2001 completed the transformation of Belgium into a federal state. The country's three regions and three communities have far-reaching autonomy with their own governments and legislative assemblies and with own funding arrangements, which can only be changed by a special majority of the federal parliament. These arrangements are essentially based on the allocation of part of personal income tax and VAT revenues, and on own regional taxes. Central authority in Belgium is shared between a federal, and five regional and community governments and their corresponding assemblies which act in conjunction, and at par, with each other and whose decisions have essentially the same legal status. However, the taxing powers of each tier of government are well defined, the intergovernmental transfer system reflects a negotiated distribution that has a firm legal basis, and the expenditure functions of each tier are well distinguished by jurisdiction with little overlap. The main complicating factor is the need for intergovernmental arrangements to accommodate institutional features that reflect linguistic and cultural differences between Belgium's regions and communities. 


\section{The legal and administrative framework for budget management}

\section{The legal framework for management of public funds is comprehensive, but} also complex and not transparent for non-experts.

The Belgian Constitution (art. 170-181) specifies the basic requirement for the executive at all levels of government to submit annual expenditure and revenue laws for the scrutiny and approval by the legislature. It also introduces the main principles of the budget process - i.e., that the process is to be annual, that there is to be no expenditure without appropriation, that all government spending is to be included in the budget, that there is to be no earmarking of revenues, that the state treasury is to be used for collecting revenues, and that discussion of the budget be in the public domain. A sizeable body of laws and royal degrees has specified these general principles, and in many cases also introduced exceptions to them. Budget legislation has developed over time, with new legislation often expanding on existing legislation, or only partially replacing old legislation. In spite of the many changes, Belgium's budget process still retains many characteristics of the traditional French budget system. A 1991 Royal Decree establishes a consolidated version of the main budget process legislation, notably the budget laws enacted in 1846, 1963 and 1989. The decree prescribes, amongst others, that a budget bill be sent to Parliament by October 31 of the pre-budget year with accompanying documentation, including a budget analysis and overview, a report on the national economy, a financial report, a report on population aging, and multi-year forward projections.

\section{The overall budget law framework is complex and fragmented, reflecting ad hoc reforms of budget planning, execution and control.}

In May 2003, new budget management legislation was approved bringing a number of innovations to the budget process, and to audit and accounting practices. These innovations include the introduction of double entry book keeping and accrual accounting standards, the creation of internal audit units in departments and agencies, and a further reorientation of the Court of Audit toward ex-post and performancerelated audits. Depending on the decision of the government level in question, this law will come fully into force during 2008-10 (2008 for the reforms pertaining to the Court of Audit). Government accounting innovations may be scaled back in the meantime, to the extent that assets and liabilities will not be accounted for, and those related to non-financial transactions such as depreciation, provisioning and revaluation will not be implemented. The accounting basis of expenditures will be shifted from a cash to a transaction (or accrual) basis.

\section{The responsibilities for the budget process have been divided between various institutions and levels of government. \\ 1.1.3, 1.2.1}

At the federal level, the Ministry of Finance is responsible for revenues and financing, while the Ministry of the Budget prepares the expenditure budget. The regions and communities have a unified Ministry of Budget and Finance. Of increasing importance for fiscal management is the borrowing requirements section of the High Finance Council, which helps coordinate fiscal policy and decision-making, provides advice on the budget balance targets for general government, and proposes an allocation of the overall general government balance target between the federal government and the regional and community governments (Box 4). 


\section{Box 4. The High Council of Finance}

The High Council of Finance plays a key fiscal policy coordination role. The main functions of the Council are: (i) to advise all tiers of government on the appropriate target for the general government balance and its distribution among government tiers; and (ii) to provide medium-term fiscal scenarios and make recommendations on macro fiscal policy and structural fiscal issues, more generally; in the latter case, a particular focus has been on the fiscal impact of population aging in Belgium. The Council consists of a section on "Public Sector Borrowing Requirements" and one on "Taxation and Social Contributions," and a Study Group on Aging.

The borrowing requirements section of the Council annually publishes an assessment of the implementation of Belgium's Stability Program and recommendations on fiscal policy, including with respect to the budget balances of the different levels of government. It also has been deeply involved in revisions to intergovernmental fiscal relations, though its regular advice is generally given in the context of an unchanged framework. Its twelve individual members are appointed by the federal Budget and Finance Ministers for a fixed term of five years; they are functionally independent and typically are drawn from the civil servants, the central bank, and academia. In carrying out its functions, this section of the Council receives support from the Study Department of the Finance Ministry, which serves as its secretariat, and from the Central Bank. Its recommendations have tended to be adopted by the political level, which over time has added to the credibility and prestige of the Council. If deemed necessary, the recommendations are first discussed in the interministerial budget and finance conference (composed of the budget and finance ministers of the federal, regional, and community governments) and at a later stage discussed in the Comité de Concertation (the general political coordination committee of the federal, community and regional governments comprising both the prime ministers and the budget and finance ministers of the respective governments).

The effectiveness of the Council's advice, and its stature, depend in part on the ability of its members to balance fiscal realities and acceptable political compromise. Internally the Council reaches consensus on issues before offering advice. The recommendations of its borrowing requirements section form the basis for political agreements between government tiers. The coordination mechanisms have helped direct fiscal policies at all levels of government and for the whole of government onto clear objectives, including compliance with EU and EMU requirements and, more recently, addressing the challenges from population aging. Consensual action and peer pressure have ensured compliance with agreed fiscal targets, and avoided inter-governmental tensions in the decentralized conduct of expenditure and, especially, tax policies.

The High Council of Finance was largely in-operational during 2004-06 in the absence of effective mechanisms to ensure its continuity when mandates of members expired. The decisions of the Comite de Concertation on the allocation of fiscal targets are not made available in full to the public, and the agreed fiscal targets are not backed by an understanding on the measures to achieve them.

\section{All tiers of governments are allowed to issue debt, though with some restrictions. 1.1 .3}

The public debt at the federal level is issued by the Minister of Finance. The lower levels of government can issue debt, with some restrictions in case of significant deviations from the agreed balance targets and the federal minister of finance has to be notified of the incurrence of foreign currency debt by the regions and communities. 


\section{The use of Public Private Partnerships (PPPs) to finance public investments} has increased, but they lack a clear legal and operational framework. 1.1 .5 PPPs have made room for extra investment expenditure in the context of the ESA-95 accounting rules, but have exposed governments to risk sharing with private enterprises. ${ }^{11}$ There is no general legal framework for PPPs, and-with the exception of the Flemish government, which has created a Knowledge Centre for PPPs ${ }^{12}$ governments have not provided much guidance to ministries and agencies as to the appropriateness of PPPs with respect to costs, benefits and risks. The Inspectorate of Finances and Budget Ministries are involved in approval of individual contracts. There is no systematic reporting on PPPs and their costs and risks in the budget documentation.

\section{The mechanisms for the coordination and management of budgetary and extrabudgetary activities are reasonably well defined.}

The social security sector is the main part of central government that is managed outside the budget process. It comprises around 20 percent of GDP and about 40 percent of general government expenditure, and is for the largest part financed through social security contributions. The budgets of the social security institutions are discussed with the social partners and other stakeholders and approved by their supervisory boards, with final approval by the supervising Minister. This ensures consistency with overall fiscal policy considerations of the federal government. In addition to direct transfers from the budget to the social security funds, a number of "alternative financing" mechanisms have been set up to compensate the social sector for the loss of certain contribution revenues as a result of government policies. The "alternative financing" arrangements are each year adjusted and modified as part of the overall budget negotiation process, which has reduced their transparency.

\section{The social security sector comprises an institution responsible for collections and other institutions responsible for spending under different social programs.}

These expenditure institutions typically carry out regulatory, budgeting, monitoring and reporting responsibilities for their respective programs. They have their own accounting systems - generally based on commercial accounting principles - prepare their own budget documents, and put together and present their own final accounts (in some cases with a significant delay).

\section{The federal budget includes a sizeable number of "budgetary funds" which} are used to earmark a certain revenue stream to a specific spending purpose. 1.1.3 Expenditure of these funds is limited by the revenues received. If the planned appropriation and related funding is exceeded, the line ministry has to seek approval of the Minister of Budget and, formally but not in practice, Parliament. To avoid overuse of such "on-budget" funds, legislation adopted in 1990 requires that all such funds be approved by law.

\footnotetext{
${ }^{11}$ Eurostat decision from February $11^{\text {th }}, 2004$ on the treatment of public-private partnerships stating that assets involved in such partnership should be classified off balance sheet for government if the private partner bears: (i) the construction risk; and (ii) at least one of either availability or demand risk.

${ }^{12}$ More information, including a list of PPP projects undertaken in Flanders, can be found at the centre's website, http://www2.vlaanderen.be/pps/english/index.html.
} 


\section{The legal and administrative framework for tax policy and administration}

21. All taxes are based in law and tax legislation is generally well publicized. 1.2.1 Article 170 of the Constitution prescribes for all levels of government that taxes can only be imposed through a legislative act; its article 172 adds that no exemption or reduction of taxes can be established except by such act. The Constitution (Article 171) also requires taxes to the benefit of the federal government, communities, or regions to be voted on an annual basis, and the rules which determine these taxes to be renewed every year. The main tax laws - notably those covering the personal income tax and the VAT - have been codified and, together with other commonly applied federal tax legislation, posted on a special Ministry of Finance website. ${ }^{13}$ Background information that can facilitate the interpretation of this legislation, including administrative circulars, advance rulings, and court decisions, is also provided to the public through this website. ${ }^{14}$ A major and systematic effort to simplify federal tax legislation is ongoing, in spite of which it is still perceived as complex and timeconsuming by civil servants and the broader public alike.

\section{New tax policy initiatives at the federal level are presented and discussed with the overall budget proposals.

The broad tax policy objectives and main measures are spelled out in the budget memorandum, with further detail and costing of individual measures in the revenue budget documentation. The capacity to project the impact of tax measures continues to have some weakness, especially with regard to longer term projections, and the use of independent official advisory bodies such as the taxation section of the High Finance Council and the Federal Planning Bureau remains too limited. Parliamentary discussions provide an opportunity for further analysis of the nature and expected impact of specific tax proposals. ${ }^{15}$ New tax legislation usually is adopted in tandem with the budget, but in a separate act - the so-called Programma Wet/Loi Programme. This act also contains a range of non-revenue measures to support budget implementation - for instance employment and labor market measures - which some see as diluting the focus on tax policy issues. Similar arrangements apply at the community and regional level.

\section{The legal framework governing tax administration is transparent, and overall well integrated with the corresponding tax legislation.}

General tax administration is one of the three core services within the Finance Ministry (together with the patrimonial services and the Treasury), and is organized along both functional and taxpayer segment lines. ${ }^{16}$ Traditionally its operations and

\footnotetext{
${ }^{13}$ At http://www.fisconet.fgov.be.

${ }^{14}$ The Ministry of Finance and some of Belgium's major financial institutions and accounting firms publish surveys of the main tax legislation in Belgium; the Ministry's annually updated survey is made available at http://www.docufin.fgov.be/intersalgen/thema/publicaties/memento/memento.htm. Summary information on the country's tax system is also made available at the http://www.invest.belgium.be website set up for foreign investors.
}

${ }^{15}$ Key recent tax reforms include the law of August $10^{\text {th }}, 2001$ reforming the Personal Income Tax, and the Law of June $22^{\text {th }}, 2005$ establishing a notional interest deduction for risk capital.

${ }^{16}$ In addition to services handling, respectively, customs and excise, fight against fraud, and tax collection, the tax administration also comprises the Administration of the Taxation of Companies and of Income, which itself is organized according to three taxpayer segments. Each of these units is

(Continued...) 
communication with the public have been quite fragmented. However, a major reform programme is ongoing and aims to improve the tax administration's performance through new work methods, re-engineered business processes and on-line service provision. The annual report of the general tax administration includes information on the various services and their reform progress, including in matters of information and communication technology. ${ }^{17}$ Tax collection procedures are audited by the Court of Audit, which has published a number of reports covering them in various aspects.

\section{A broad modernization philosophy is apparent in new advance ruling} arrangements and the move toward a single tax file (a single taxpayer identification number is already in use).

An advanced ruling system which provides legal security as to the tax treatment of a planned transaction has been in place since 1991 and strengthened significantly in 2002, notably through the creation of a dedicated ruling service within the Ministry. Advance rulings bind the administration for a period not exceeding five years. They are published anonymously on the web, and are summarized in an annual report presented to the House of Representatives. As to the single tax account, efforts are now under way to link the databases of the Ministry of Finance and other federal public services, which would allow an integrated assessment and collection of taxes.

\section{Taxpayers' rights and obligations are clearly spelled out, and dispute procedures well laid out.}

To protect taxpayers in criminal tax cases, in 1986 an office of the King's Attorney specializing in tax matters was created and a "charter of the taxpayer" introduced. As a result, tax administration officials can only initiate a criminal case following authorization from their regional director or the general director of the special tax inspection, and their role is limited to that of witnesses. Inquiries and prosecution for tax violations are reserved for a number of substitutes to the King's Attorney with special expertise in tax matters. The taxpayer's position in civil cases was strengthened through a 1999 legal reform which transferred all tax disputes to the judiciary, to newly established tax divisions of the courts of first instance. ${ }^{18}$ More generally, several provisions in the charter of public service users also apply to the tax administration and contribute to a better communication with the tax payer, greater transparency, and customer orientation with respect to administrative decisions (see above). In the same vein, a 2002 ministerial circular spells out a number of principles such as courtesy, open communication and restraint in the use of investigation and control rights that should guide the interaction between tax administration and citizens.

composed of central and external services. The former are in charge of customer relationship and work management issues; the latter carry out operational activities, such as records management and in-depth control.

\footnotetext{
${ }^{17}$ The last activity report, which relates to 2006, is available at the following address: http:/www.fiscus.fgov.be/interfaabfr/Jaarverslag2006/JV2006.htm.

${ }^{18}$ Laws of March $15^{\text {th }}, 1999$ related to tax litigations and of March $23^{\text {th }}, 1999$ related to the organisation of the judicial system with regard to taxation.
} 


\section{Public servants' code of behavior and anti-corruption activity}

26. There is no comprehensive code of behavior for civil servants, but elements are covered by various laws and statements and the jurisprudence of the High Administrative Court.

A royal decree of 1937 governs the basic rights and duties of federal civil servants, including the possibility of disciplinary measures given certain inappropriate behavior. This decree has been amended and modified numerous times. The authorities' view is that it has performed reasonably well in combating corruption and abuse of office. The basic principles of a code of conduct for federal civil servants were published in August 2007. A royal decree of 2000 spells out general principles governing the federal civil service that apply to civil servants affiliated with communities and regions. These civil servants are otherwise governed by separate legislation, which also includes key elements of a modern code of conduct. The present codes of behavior are not very explicit on what constitutes conflict of interest, what limitations there are on political activities, and what rules apply for remuneration of secondary activities. Since the 1990s, a string of administrative modernization legislation has strengthened the focus on the quality of service provision to the citizen. New incentives for civil servants to implement these initiatives have remained limited.

\section{B. Open Budget Preparation, Execution, and Reporting}

\section{The budget preparation process: clarity and consistency of process and presentation}

\section{The annual budget process is open and the presentation broadly consistent} with international standards.

The budget process is guided by a multi-year coalition agreement that outlines the main expenditure priorities and fiscal policy targets. Budget formulation starts in May of the pre-budget year with a budget circular from the Ministry of the Budget providing macroeconomic inputs and instructing government departments and agencies on requirements for a first draft budget (see Box 5). Unlike in some OECD countries, Belgium does not have a "two-step budget preparation process," with a strategic phase early in the process (see Box 6). As a result, the draft budgets mostly have an incremental character relative to the previous year.

\section{Budget preparation at the level of the executive follows a well-established} process.

Inspectors of Finances accredited to the department in question advise on its draft budget by the end of May, both to the functional minister and the Minister of Budget. The report assesses the accuracy of the budget estimates, the legality of the proposed expenditure, and, to a limited extent, the efficiency and effectiveness of the proposals. The budget preparation process continues through June-September. In June, bilateral budget negotiations take place between the Budget Minister and the functional ministers; however, in contrast with other countries, the Ministry of Budget is not 


\section{Box 5. The Budget Preparation Process}

\begin{tabular}{|c|c|c|}
\hline Due dates & Activities & Legal basis \\
\hline \multicolumn{3}{|c|}{$\begin{array}{l}\text { The fiscal year is set on a calendar-year basis by the constitution and budget process legislation. } \\
\text { The main steps in the process are as follows: }\end{array}$} \\
\hline May & $\begin{array}{l}\text { Sending out of Budget Circular by Ministry of Budget }+ \\
\text { Advice of Inspector of Finances }\end{array}$ & \\
\hline June & $\begin{array}{l}\text { Bilateral discussion between spending ministries and Minister } \\
\text { of Budget }\end{array}$ & \\
\hline $\begin{array}{l}\text { July- } \\
\text { September }\end{array}$ & $\begin{array}{l}\text { Update of macro forecasts, advice of High Council of Finance } \\
\text { on allocation of fiscal target, bilateral discussions in Cabinet }\end{array}$ & \\
\hline October & $\begin{array}{l}\text { Cabinet-wide decision-making on remaining budget issues; } \\
\text { submission of draft expenditure and revenue laws to } \\
\text { parliament }\end{array}$ & $\begin{array}{l}\text { Constitution, } \\
\text { Coordinated } \\
\text { Budget } \\
\text { Legislation }\end{array}$ \\
\hline $\begin{array}{l}\text { November- } \\
\text { December }\end{array}$ & $\begin{array}{l}\text { Discussion in parliamentary committees, budget committee } \\
\text { and full session of parliament; approval of budget by } \\
\text { parliament }\end{array}$ & Constitution \\
\hline February & $\begin{array}{l}\text { "budget-control" process, i.e. early calibration of budget on } \\
\text { further update of macro forecasts and department costing }\end{array}$ & \\
\hline
\end{tabular}

directly engaged in discussing and reviewing the policy direction of the expenditure proposals. In July, the High Finance Council publishes its recommendations on the overall fiscal targets and allocation between levels of government. In September, the Federal Planning Bureau presents an update of the macroeconomic outlook, and remaining issues are discussed in so-called post bilateral discussions and by the full cabinet in special session.

\section{Parliamentary discussion and approval bring the budget preparation process to completion by year-end.

The Ministry of Budget finalizes expenditure and revenue budgets and submits them, together with supporting documentation, as two draft laws to parliament before October $30^{\text {th }}$. The documentation includes a general statement on the budget and the main new policy initiatives. Parliament receives separately (and usually somewhat earlier) the policy statements of line ministries which further explain the policy and expenditure decisions of respective functional ministries. Attached to both budgets are comments of the Court of Audit mainly on issues of legality, regularity and accuracy of the proposed budget. In the period November-December Parliament reviews the budget in three fora: functional committees (which discuss the expenditure proposals of functional ministries), the budget committee and the assembly in full session. Parliament has the right to amend the budget, but the political process in practice limits the scope for significant changes to the executive's proposals. Parliament should approve the budget by end of December, but there is a legal provision allowing for 


\title{
Box 6. The Medium-Term Budgetary Framework
}

\begin{abstract}
The Medium-term Budgetary Framework (MTBF) is considered by many OECD countries as an essential public financial management tool for planning, allocating and controlling government expenditures. It is seen to have three main benefits: it facilitates macroeconomic control by placing both fiscal and expenditure policy in a medium-term setting; it links strategic planning and decision-making to the budget process; and it improves the effectiveness and efficiency of government expenditure through more thorough review and evaluation of expenditure programs. MTBFs also improve the quality and stability of the budget process, because they separate the process into a strategic decision-making phase and a detailed budget preparation phase.
\end{abstract}

\section{Different countries have developed different types of MTBFs, but the main building} blocks are similar. MTBFs always involve confronting estimates of top-down medium-term resource availability with bottom-up medium-term expenditure estimates, both of ongoing and new expenditure programs, and reconciling these through Cabinet decision-making. These decisions are then formalized in expenditure ceilings over the planning horizon of the MTBF, usually 3 to 5 years. MTBFs commonly revisit this decision-making every year. It is thus a rolling form of budgetary planning and decision-making, adjusting each year to new views on the macroeconomic situation and strategic priorities. The extent to which expenditure priorities are revisited will vary from country to country.

\section{A crucial element of a full MTBF is that expenditure estimates are in part based on} "bottom-up" information of the line ministries. This means that they take into account the cost drivers behind the various government programs. While MTBFs have been formulated on the basis of economic/object of expenditure type budget classifications - which focus on expenditure inputs - their effectiveness increases significantly once program budgeting is introduced. This allows linkage of the government's strategic priorities to budgetary decisionmaking. It also allows more accurate tracking and costing of expenditure over future years.

MTBFs are reinforced if the cabinet decision-making on them is made public. A large number of countries publish the macro-fiscal outlook, the strategic choices government has made, and the expenditure ceilings for the medium-term in a comprehensive document early in the pre-budget year. In some cases that document is not only approved by cabinet but also discussed and approved by parliament. The annual budget then becomes a further detailing of this strategic document, updated mainly to take into account the latest macroeconomic insights, and final decision-making by cabinet.

delayed approval. ${ }^{19}$ A supplementary budget can adjust the budget in the course of the the budget year. The so-called budget control process in March calibrates the budget to the latest macroeconomic figures and the updated needs of departments, and typically prompts a number of changes to the budget itself, which have to be approved by Parliament before June $30^{\mathrm{th}}$.

\footnotetext{
${ }^{19}$ There is a legal provision for possible delayed approval (as has been the case with the 2008 budget): Parliament adopts a law authorizing tax collection and spending based on provisional twelfths.
} 
30. A major weakness of the budget process and its supporting documentation is the lack of well-defined performance orientation.

3.2.2

In its absence, it is unclear what government expenditure aims to achieve and when it has achieved certain goals. While the budget classification contains some programmatic elements, and the budget documentation provides some information on the goals of programs, there is not a systematic link to concrete and measurable targets. The lack of performance orientation also complicates the task of the Court of Audit when it assesses if government expenditure is being used effectively and efficiently (see below). In Flanders performance budgeting reforms are to be introduced in the coming years, but overall Belgium is lagging its EU peers in this area.

\section{A perhaps even more fundamental weakness of the budget preparation process is the lack of quality of the multi-year projections. 3.2 .2} At the federal level, relatively detailed multi-year expenditure and revenue projections are presented in the general statement included in the budget documents, but the expenditure estimates are still based on macro-projections and extrapolation rather than costing of individual expenditure items, or reflect policy targets rather than projections. The majority of regions and communities prepare and publish multi-year projections, the expenditure side of which also tends to be primarily based on extrapolation. A consequence of extrapolated multi-year expenditure estimates is that agreed fiscal frameworks and targets in the context of Belgium's internal stability pact are not adequately supported by policy measures. Thus the fiscal targets of governments need to be monitored regularly and renegotiated frequently, even during the budget year.

\section{The main budget accounting system is a cash-based single entry system. 3.3.1}

Budget accounts at the federal level are kept at the Treasury and compiled on the basis of payment orders executed through the automated budget execution system linking the Treasury and the functional ministries. Accounts are, however, also kept by the Court of Audit and, at a more disaggregated level, by the functional ministries themselves. Budget expenditure is classified according to a mix of institutional, programmatic and economic categories. The economic classification is compatible with GFSM 1986; translation to GFSM 2001 and ESA 95 is done ex-post through bridging tables. The chart of accounts incorporates administrative, economic, functional, and program classifications. Agencies outside the direct management responsibility of departments are using an accrual-based, double bookkeeping accounting system.

\section{The budget accounting system of the communities and regions is also a hybrid.

Their basic accounting system is cash-based-except in Brussels where a form of accrual accounting has been introduced - and agencies operate under accrual concepts. The chart of accounts is harmonized between communities, regions and the federal government with respect to the economic and functional classification. Municipal governments introduced a double entry accounting system in the mid-1990s.

\section{The lack of a single accounting standard within and between governments} complicates budget planning, execution and reporting.

Consolidated in-year data and next year budget estimates are based on approximations rather than on actual consolidation. Final consolidated general government data are 
produced by the National Accounts Institute in September of year $\mathrm{t}+1$. Due to poor reporting by some agencies and by local governments, data related to them are partly based on sampled information.

\section{The macroeconomic framework and policy basis for the budget}

\section{The overall balance of general government is the main indicator of the fiscal position in the budget, and is monitored during the year.

The key indicator of the fiscal position is net lending/borrowing of general government, as defined under the excessive deficit procedure. ${ }^{20}$ The general statement included in the budget documentation provides a detailed explanation as to how the national budget concepts and data are transposed into the ESA 95 framework. ${ }^{21}$ To achieve the objectives of a continued reduction in the debt-to-GDP ratio and preparation for aging-related expenditure pressures, the government is aiming at a gradually increasing net lending position over the medium-term. The federal government and the interministerial budget and finance conference monitor general government net lending during the year, notably through at least one (March-April) indepth "budget control" exercise. The federal government tracks the general government debt position on a quarterly basis, while all six governments monitor a range of cash-based indicators on the execution of their respective budgets on a monthly basis. Within-year information on the net borrowing/lending position of the local government sector (municipalities and provinces) is not available. The NBBN also monitors the general government fiscal position during the budget year, in line with ESCB guidelines and reporting requirements. The NBBN moreover provides an in-depth analysis of fiscal policy in its Annual Report, produces research reports on selected fiscal policy topics, and prepares and publishes semi-annual general government forecasts. As quasi-fiscal activities are limited, there is no regular provision of information on the public sector balance.

\section{Budget forecasts and underlying macroeconomic assumptions are clearly presented.

Based on a legal mandate, the Federal Planning Bureau, under the authority and on behalf of the Institute for National Accounts, publishes an "economic budget" (i.e., the macroeconomic framework underlying the budget) twice a year (in February, in preparation for the March "budget control" of the current-year budget, and in September, in the context of the finalization of the year ahead budget proposal). They use a well-publicized and vetted methodology and prepare the framework independently from the finance and budget ministries. ${ }^{22}$ Formal coordination with the government is limited to a semi-annual presentation of the updated framework to the

\footnotetext{
${ }^{20}$ Under the excessive deficit procedure, general government net borrowing/net lending is defined by the ESA 95 code EDP B9, treating interest flows under swaps and forward rate agreements as interest (rather than financial flows).

${ }^{21}$ This transposition is also clarified in a May 2005 document by the Court of Audit on the ESA 95 methodology.

${ }^{22}$ Henri Bogaert, Ludovic Dobbelaere, Bart Hertveldt, and Igor Lebrun, "Fiscal councils, independent forecasts, and the budgetary process: lessons from the Belgian case," Planning Bureau Working Paper no. 04-06, June 2006; and Federal Planning Bureau, "Tools and methods used at the Federal Planning Bureau, Planning Bureau Working Paper no. 07-06, September 2006, Brussels: Federal Planning Bureau; both available at http://www.plan.be.
} 
cabinet. The macroeconomic framework and the budget forecasts themselves are clearly presented and explained, including the underlying methodology, in the annual budget documents.

\section{Medium-term planning and analysis of fiscal risks}

\section{A statement on medium-term fiscal policy objectives is included in the budget document, and fiscal sustainability issues are presented. 3.1 .1} The federal government's medium-term objectives are presented and discussed in both its annual budget documents and, in the format prescribed by the European Commission, the annual updates of Belgium's Stability Program. These two sets of documents, which are prepared in tandem, quantify and motivate the general government balance targets for the year ahead and the following three years, and discuss in detail fiscal sustainability issues, notably those related to population aging. ${ }^{23}$ The federal government budget documents in addition provide medium-term spending estimates for selected economic items; but they do not, nor does the Stability Program, include estimated envelopes for disaggregated functional spending groups.

\section{Numerical fiscal rules are used in the budget process.}

Fiscal policy is guided by a rule specifying the targeted annual surplus until 2012. According to this rule, which is enshrined in law, general government had to achieve a net lending position of 0.3 percent of GDP in 2007 and further strengthen this position by 0.2 percentage point of GDP every year during 2008-12. The annual surpluses have to be allocated to the Silver Fund, a notional fund created in 2001 with the mandate to secure funding of the projected increase in government pension liabilities during 2010-30. These rules are complemented by the internal stability pact, which, for the period until 2010, allocates the general government surplus target further across levels of government.

\section{Estimates of new initiatives and ongoing costs of government policies are not always clearly distinguished in the budget documents. 3.1 .4}

The Court of Audit in this regard notes that the multi-year impact of new spending policies is often not assessed accurately. Similarly, the revenue impact of new tax measures is not always easy to determine from budget documentation. In other cases the impact of new revenue measures is estimated without direct connection to the budget, for instance in studies by outside consultants. In-depth analysis of new expenditure and revenue measures is further hampered by the lack of disaggregation and the sometimes rather poor quality of multi-year expenditure and revenue estimates presented in the budget (see above).

\footnotetext{
${ }^{23}$ The High Finance Council's study group on population aging in April/May issues a report on the economic and social consequences of aging, including its fiscal costs. The Council's borrowing requirement section in June/July publishes a report recommending for all levels of government specific budgetary targets that reflect the estimated fiscal costs of aging.
} 


\section{The sensitivity of budget estimates to changes in economic variables is assessed and fiscal risks are discussed in the budget.

The sensitivity of budget estimates to changes in economic variables is assessed systematically for the European Commission and in economic studies prepared by the Federal Planning Bureau, but are not systematically included in the budget documentation. Fiscal risks are discussed in the budget documentation on an occasional basis, but not reported on comprehensively. Sensitivity of fiscal outcomes to changes in interest rates and economic growth are presented in the annually updated Stability Programs prepared for the EU. However this information is not presented systematically in budget documentation. Similarly, the budget documentation of regions and communities lacks comprehensive analysis of fiscal risks. This is perhaps exacerbated by the fact that regions and communities do not have a strong capacity to monitor and project sub-national economic developments. Fiscal risk originating from contingent liabilities such as government guarantees and PPPs are not presented systematically, in the form of an overview table. Fiscal risks specifically related to population aging, in addition to being covered in the Stability Programs, are analyzed in detail in the annual Aging Reports published by the High Finance Council's Study Group on Aging. Quasi-fiscal activities by government-owned enterprise are reportedly limited.

\section{Clarity of control of budget execution}

\section{Basic accounting and internal control procedures are in place. $\quad 3.3 .1$}

The budget execution process has adequate safeguards The internal control framework of government is still very much rooted in the French tradition. An advisory Inspectorate of Finances provides an ex ante opinion on non-recurrent expenditures with a significant budgetary impact, notably subsidies and procurement of works, goods, and services for amounts above a certain level. The Inspectorate also advises on political or regulatory decisions leading up to the contracting of goods and services. Controllers of Commitments, officials of the Ministry of Budget assigned to work in the functional ministries, verify compliance with accounting and administrative rules, authorize commitments and reserve the necessary budget credits. As a second layer of control, the Court of Audit approves the legitimacy and regularity of all expenditure. A sizeable part of this control is ex ante, before the payment of invoices is instructed. Functional ministries themselves have their own systems of control. For example, in general there is a separation of responsibilities for payment order and payment itself (and management of accounts). ${ }^{24}$

\section{The internal budget control system is inefficient and overly focused on legality.

The Court of Audit's control and the internal control procedures of the functional ministries tend to be time-consuming and labor intensive in particular. The new 2003 budget legislation eliminates the ex-ante control of the Court of Audit and puts the emphasis on ex-post audits by the Court. This new legislation also sets forth guidelines to set up internal audit units in the functional ministries, the development of which is still at an early stage. At the level of the administration, the complementarity between

\footnotetext{
${ }^{24}$ In the case of decentralized payment by the line ministry itself. Larger payments of federal, community and regional government are all paid through a central treasury system.
} 
the new internal audit units and the Inspectorate of Finance will need to be clarified. Unlike the Inspectorate, these new units will not be in a position to ex ante advice on expenditure decisions and to review such decisions initiated by Ministerial services ("cabinet") directly. Larger payments of federal, community and regional government are paid through a central treasury system operated by the respective treasuries. The treasury of the federal government keeps its main account at the central bank, while payments are made through the financial branch of the Post Office. The communities and regions have set up their own treasury services, and work with the KBC Bank (Flanders) and the former bank for municipalities, Dexia (Brussels region, French Community and Walloon region).

\section{Both commitments and cash expenditures are budgeted and controlled. 3.3.3}

The budget is a commitment/expenditure budget in the sense that both are appropriated by parliament. Commitments and expenditures are also controlled separately. However, the central treasury system does not monitor incoming invoices of line ministries and agencies, or enforce their timely payment. Thus, before they are submitted, invoices can be kept for relatively long periods at the financial departments of functional ministries. In the absence of invoice control and full synchronization between commitment and expenditure controls - for instance related to the fact that some commitment may be based on ongoing contracts or on commitments taken on in earlier years - payment arrears can result. According to press reports, several functional ministries have built up such arrears.

\section{Payment patterns and the use of accounts have not been regularly monitored.}

Neither the budget ministries nor the spending departments themselves have been systematically reviewing payment patterns. Payment statistics, a normal performance indicator for monitoring the quality of government payment processes, are not published regularly. Late payment fees are a legal obligation for government, but are not always paid in practice. The existence of a large number of treasury and regularisation accounts has further complicated the monitoring of account balances and payments. Regulations governing the opening and operation of such accounts are inadequate, and systematic information on them is lacking. A number of treasury and regularisation accounts have been kept open without active use, while others have been a vehicle for off-budget spending. A new financial management information system for the federal government that is being rolled out will have the capacity to track and report on invoices outstanding and corresponding payments, and help address the treasury and regularisation accounts-related problems.

\section{Debt and cash management practices are well coordinated and executed transparently and with professionalism.

At the end of each year, the federal Treasury develops with assistance of the Ministry of Budget a formal cash plan for federal government for the coming year. The Belgium Debt Agency uses this plan to prepare an issuance calendar, which is published ahead of time for market participants. The Debt Agency publishes an annual report on its activities, which contains an overview and analysis of the debt portfolio and market circumstances. The document also discusses past and future debt management strategies of government. Details on public debt are also included in budget and final account documentation, and published on the internet. In its activities on capital and money markets the Belgium Debt Agency follows guidelines prepared by a "Strategic Committee" which is led by the administrative head of the Treasury and in which 
senior debt agency staff participates. This Strategic Committee is also involved in major operational decisions, but day-to-day activities are managed by the Agency itself. The agency has regular informal contacts with market participants, but there is no regular formal forum for discussion on market functioning with counterparts.

Overall cash and liquidity management of the federal government is also carried out by the Debt Agency, which usually succeeds to keep the main account of government at a balance of zero at the end of the day. The government provides cash advances to the bank accounts of decentralized government services; these accounts are not zerobalanced at the end of each day. This advances arrangement facilitates the payment process by eliminating the need for itemized control over small expenditures.

\section{The regions and communities on the whole have been successful in setting up their own debt and cash management infrastructure, and they report adequately on their debt position and management.

With the exception of the French community, regional and community debt levels are low relative to the size of their budgets, and Flanders is projected to be debt-free before the end of 2008 .

47. Internal audit capacity is still weak but is being strengthened.

Belgium is slowly modernizing its internal and external audit mechanisms. An August 2007 Royal Decree requires federal line ministries and agencies to set up own internal audit units, the mandate of which extends beyond the legitimacy and regularity of expenditure. A related August 2007 Royal Decree establishes an Audit Committee for the federal government. The main tasks of the audit units will be to audit systems and institutional arrangements - rather than individual transactions. The internal audit service, however, only covers the administrative services of the functional ministries, not the Minister's own services. The Court of Audit is systematically evaluating the practices and standards of the new internal audit units at the federal level. Regions and communities appear in certain aspects to have progressed further than federal government in developing internal audit functionality. Following the introduction of the new internal audit cells, the number of layers in expenditure management has risen to five (Court of Audit, Internal Audit, Inspectorate of Finances, Controllers of Commitments, and the internal controls of line ministries and agencies themselves). As a first attempt to coordinate the various internal audit mechanisms, the Court of Audit has recently started a "Single Audit" initiative to share common information and reduce overlap in activities.

\section{Procurement rules and practices are clear, publicly available and in accordance with EU directives.

The regulations on public procurement in Belgium - specifically the laws of June 15 and June 16, 2006 - are in line with EU procurement directives. These acts require open tender procedures for all purchases of government entities (and of public utilities) above a certain monetary amount. The legislation has adequate safeguards for quality and fairness of the tendering process, as well as for recourse to independent review. Requests and results of public tenders are published in newspapers. There is, however, no annual overview of the procurement process in budget documents with an analysis of process performance indicators (such as process time, use of special procedures, number of complaints filed, etc.). At the functional ministry level the "ordonnateurs" or accounting officers are responsible for the procurement process, while the Ministry of the Budget closely monitors procurement through it budget officials placed in the ministries. The Inspectorate of Finance also plays an important role in reviewing 
tender processes, as they are allowed to give an opinion on the broader desirability of the planned contracting of goods or services.

\section{Civil service employment procedures are clear and well-understood. 3.3 .2}

All statutory employment decisions at the federal, regional and community levels are handled by a single selection agency, Selor. The procedures are standardized, transparent, and not subject to any direct political interference. Political affiliation appears to be a more significant factor at the more senior levels of the administration, in particular for the top officials appointed through the recently introduced system of temporary management contracts.

\section{Tax administration has effective internal monitoring and control mechanisms.}

The tax administrations, customs included, traditionally had an embedded inspectorate, which was charged with supervising the former's tax assessment and collection activities. An internal audit unit for tax administration services was created in 1991, and, in the context of broader efforts to create effective internal audit cells in the line ministries, was subsequently given an expanded mandate and put under the direct authority of the Chairman of the Executive Committee of the Finance Ministry. Customs duties and the traditional own EU resources are governed by the acquis communautaire; and supervision of the administrations collecting these taxes is within the competences of the European Union services. ${ }^{25}$ The integrity and professionalism of tax administration officials is safeguarded under the general civil service regulations, and further underpinned by continued professional education and the ongoing systematic modernization of the tax management system. On the occasion of the recent large-scale reorganization of Finance Ministry, the main processes used by the tax administration also have been the object of an in-depth analysis and assessment by external consultants. The efficiency and integrity of the tax administration are covered in its annual report and discussed by the House of Representatives in the context of the debate on the Ministry of Finance's budget. Inclusion in the Ministry's budget also ensures that tax administration is fully funded through standard budget mechanisms and procedures.

\section{Accounting and reporting on budget execution}

\section{The accounting system is capable of producing accurate in-year reports on central government budget outturn.

The federal government financial management information system is run by the General Accounting Department in the Treasury and linked to an automated expenditure payment system. The systems are able to produce daily expenditure data on the federal government for budget managers, but on a cash basis and with only limited detail. Monthly fiscal consolidated reports on the federal government, communities and regions are published in the Official Journal with a lag of two months or more. Budget execution data is also published on the internet, but with variable lags and in ad hoc formats. The chart of accounts underlying budget reporting consists of expenditure classifications according to institution, program, and economic and functional items. The budget classification is a mixture of the institutional,

\footnotetext{
${ }^{25}$ Among which the European anti-fraud office (OLAF).
} 
programmatic and economic classification. The budget is approved by Parliament at the program level, but the expenditure control of the Ministry of Budget is at a much more detailed level. This results in regular and extensive requests to change budget allocations during the budget year. Communities and regions in principle use the same economic and functional classification as federal government, i.e., ESA 95 and COFOG, respectively. ${ }^{26}$ The National Accounts Institute which produces data on general government, in part relies on estimation and sampling techniques for producing in-year data for consolidated general government. This is especially the case for the local government component. ${ }^{27}$ Moreover, at the federal, community and regional level, complete and timely data on the parastatals is also missing on an in-year basis.

\section{Fiscal reporting covers all of general government, but fiscal statistics are produced with some lag and at a rather high level of aggregation. 2.1.1, 2.1.5} Consolidated fiscal data for all of general government is produced by the National Accounts Institute on an annual basis and in ESA 95 format. The National Accounts Institute is responsible for sending aggregated fiscal data on general government to the EU as required under the Stability and Growth Pact; this information is made available to Eurostat within 4 months after the end of the reporting period. The National Accounts Institute also regularly transmits general government data to the ECB in accordance with ESCB requirements, for publication, mostly in the format of Euroarea aggregates, in the ECB's monthly bulletin. The Ministry of Finance's "Conjunctuurnota/Note de Conjuncture," which is published bi-monthly and available to the public, presents a range of data on the execution of the budget, in national format and with coverage of the federal government and the revenue side in particular. ${ }^{28}$ Regions and communities release selected budget execution information on their respective websites, in an ad hoc format that does not allow consolidation across governments. Outturn data for the municipalities and provinces are only available with a very long and variable lag.

\section{Budget reporting is frequent but audited reports are available on a timely basis only for the federal government.

The general statement attached to the budget documentation submitted to Parliament in October (see above) provides an overview and discussion of budget execution in the current year. The audited final accounts of federal government are available within twelve months of the end of the fiscal year, but this is not yet the case for other parts of general government. The audited final accounts of federal government, as well as those of other levels of government and the autonomous institutions, are to be submitted to the respective legislatures by October $31^{\text {st }}$ of the following year. The federal government has been able to meet this requirement, but other levels of government continue to have substantial delays in presenting their audited accounts.

\footnotetext{
${ }^{26}$ Acronym for the United Nation's Classification of the Functions of Government.

${ }^{27}$ A general data base maintained at the Ministry of the Budget contains consistent information on the finances of the federal government, communities and regions and provides an important input into the National Accounts Institute's work to produce consolidated general government data.

${ }^{28}$ A hard copy of the complete publication is available for a fee, and a selection of its government revenue tables is posted on the Ministry of Finance's website at http://www.docufin.fgov.be/intersalgfr/thema/publicaties/conj/Conj.htm.
} 
As an extreme example, audited accounts of the Brussels Capital region have been published with a delay of more than 10 years, while some other communities and regions have delays of four or more years. The delays greatly diminish the political and administrative importance of approval of the final accounts by the legislature. Efforts to reduce the delays are ongoing especially in the French Community and Flanders. All final account documentation and accompanying reports of the Court of Audit are made available to the public.

\section{Results-oriented budgeting and reporting}

54. The objectives and expected results from government activities are defined in general terms in the budget documents.

A formal performance budgeting system has not been introduced. The budget classification includes expenditures grouped by programs and activities, and the general objectives of programs are expressed in policy documentation accompanying the budget, but these objectives are not defined according to a standard methodology and cannot be linked easily to comparable performance indicators. The performance of government policies is discussed in the budget documentation but not in a systematic way; similarly, independent evaluation of government programs is organized from time to time, but not on a systematic basis. The Court of Audit views the lack of a performance framework as a great hindrance in determining the effectiveness of government spending.

\section{Public Availability of Information}

\section{Fiscal information is quite comprehensive and readily available to the public and there is a clear commitment to improve the timely provision of information.}

The requirements for publishing budget, final accounts and in-year budget reports are specified by law. All tiers of government are making considerable efforts to improve the timely availability of audited accounts, but much more needs to be done. They also have made substantial efforts to develop web-based access to fiscal information, importantly through the websites of the Ministries of Finance and the Budget. ${ }^{29}$

\section{The coverage and quality of budget documents}

\section{The budget documents cover central government fiscal activities} comprehensively and provide summary data on general government.

The federal government budget presents the fiscal aggregates of general government such as the overall deficit, expenditures and revenues. Information on expenditures of provinces and municipalities is, however, very limited. The federal budget documentation also provides a detailed discussion of revenues collected on behalf of communities and regions. The detail of information in federal budget documents in places exceeds what the aims of clarity and transparency would warrant.

\footnotetext{
${ }^{29}$ At respectively http://www.minfin.fgov.be and http://www.begroting.be.
} 
The budget documentation is quite open about defense expenditures, detailing these at the same level as the expenditure of other line ministries. The capital budget of the Ministry of Defense is also overall transparent on the type, cost and number of weapon systems to be purchased.

\section{Past and forecast fiscal data in the budget}

58. The budget documentation discloses the main fiscal aggregates for the two years prior to the budget year and three years beyond the budget year.

The general statement accompanying the Budget-which is part of the budget documentation - provides aggregate expenditure and revenue data looking two years back from the budget year and three years forward past the budget year. Detailed fouryear expenditure projections are presented in annexes to the budget documents, but not at the appropriation level that would allow for insight in the development of expenditure programs over the medium-term given all approved policies. Thus the multi-year figures do not represent a baseline of expenditure, but rather a target level of expenditure; how this target level of expenditure is to be achieved is not clearly explained. The overview of aggregate expenditures and revenues of communities and regions is also presented on a multi-year basis; but the projections again are more political targets than baseline expenditure items. The level of detail is less than that for the multi-year overviews in the federal budget.

\section{Budget treatment of off-budget fiscal activity}

\section{There is no systematic and comprehensive reporting of contingent liabilities in the budget.

The budget documentation includes case-by-case information on guarantees provided to the private sector or to other parts of the public sector, but does not include an overview table (indicating such factors as the outstanding contingent liability by government, the destination sector, the level of risk involved, the type of contingent liability, and the remuneration paid for the guarantee). Also, there is no overview of called claims, which is a key input for ex-post risk analysis. At the same time, new financing vehicles involving private sector participation are being introduced that imply a different and often increased contingent risk profile for government compared to outright ownership. ${ }^{30}$ In the regions and communities, especially Flanders, PPPs are increasingly used to finance infrastructure projects, but no systematic information on their importance and the risks involved is available.

\section{Statements on tax expenditures are included in the budget documents, but} only on an ex-post basis.

The federal government has a legal obligation to every year produce a list which identifies and estimates the impact of all measures (exemptions, allowances, or credits) that may lower revenues. ${ }^{31}$ Both direct and indirect taxes are covered, but not fees and

\footnotetext{
${ }^{30}$ One such vehicle is the sale of federal government buildings to real estate financing companies in tandem with operational lease contracts for the continued use of this real estate.

${ }^{31}$ Tax expenditures in the Belgian context are defined by the High Council of Finance as "A loss of tax revenue attributable to tax advantages resulting from a derogation to the general tax regime relating to a
}

(Continued...) 
charges. The budgetary cost is estimated when possible, for indirect taxes with one year delay, and for direct taxes with a two year delay, but in practice the lags are much longer (the most recent estimate was published in February 2006, and presents data through 2003). The list is published as an annex to the annual revenue budget and subsequently, in summary format, made available to the broader public through the Ministry of Finance's research bulletin (Documentatieblad/Bulletin de Documentation). The two largest tax expenditures relate to tax reductions on pensions and other replacement income and to tax incentives for the purchase of a first residence and long-term savings, which together represent a loss of revenue of about 5 percent of the tax yield. Communities and regions do not report on tax expenditure, in part reflecting their limited tax autonomy.

\section{The estimated cost of quasi-fiscal activities is not included in the budget documents, though these activities are not extensive. 2.1 .3}

The quasi-fiscal activities carried out by government-owned enterprises are limited. Under the management contract arrangements, the public service obligations taken on by such enterprises are clearly identified and overall properly budgeted and reported.

At the federal level, some of the activities of the Federal Participation and Investment Company, notably capital injections in other government or public sector agents, bear quasi-fiscal characteristics. More generally and more importantly, the federal government is accepting non-market returns for extended periods on most of its equity participations - as are regions and communities. Estimates of the associated opportunity costs are not presented in the budget documents.

\section{Publication of data on debt and financial assets}

\section{Information on gross public debt is published comprehensively in the budget documentation, through an annual report, and on the internet.

The budget documentation provides extensive information on the outstanding debt stock, including by instrument, currency of issue, and maturity structure. The Belgium Debt Agency produces the same information on an ongoing basis, and places it on the internet with some delay. The Agency also produces an annual report with an in-depth presentation and analysis of outstanding debt and its structure.

\section{Information on government financial and physical assets is published infrequently and at an aggregated level.}

The Inventory of State Property Committee publishes a full balance sheet of the federal government every ten years (the most recent one was published in 1999). Financial assets are included in this balance sheet but in aggregate format only. Given the low frequency of this publication and the fact that the information is provided after a lag of two to three years, it is not suited for tracking changes in ownership of specific government assets, and it does not allow the financial results of asset sales to be

specific tax, intended to assist certain taxpayers or to encourage certain economic, social and cultural activities, and which could be replaced by a direct cash subsidy." The list's coverage extends beyond this concept of tax expenditure: any tax relief or tax credit is included, and the list indicates whether that provision is considered a tax expenditure or a provision of the benchmark tax system; see Christian Valenduc, "From Tax Expenditure Reporting to Tax Policy Analysis: Some Experience from Belgium," in Hana Polackova Brixi, Christian Valenduc and Zhicheng Li Swift (editors), "Tax ExpendituresShedding light on government spending through the tax system," Washington DC: The World Bank, 2004. 
monitored by the legislature. Financial assets are reported at market value, if securities are marketable, and otherwise at book value. The inventory of physical assets is based on listing of properties and valuation against standard cost and revaluations with general indexes; these values can differ significantly from market-based assessments. While balance sheet information for both financial and physical assets is extrapolated on an annual basis, its quality does not appear to warrant use for budgeting and reporting purposes. Even less information is available on the asset position of regions and communities, with the exception of the Brussels regional government - which keeps a full double entry bookkeeping, including of financial and physical assets.

\section{Commitment to timely publication of fiscal data}

\section{Formal commitments for regular publication of fiscal data have been made and release data are announced in some cases.

The requirement to publish fiscal data in budget and final accounts documents on an annual basis is established by law for the various levels of government; the legislation also specifies the dates, or ultimate dates, at which these documents should be provided. As discussed, the audited final accounts of many of the regional and community entities have had and still suffer serious delays. The treasuries of the various layers of government have an obligation to publish cash data on expenditure, revenues and debt in the Official Journal on a monthly basis. The exact publication date varies however. There usually is a delay in publication of a few months. Fiscal data is provided on a regular basis to the EU, in the context of fiscal coordination and the excessive deficit procedure under the Maastricht Treaty and under the ESA 95 regulation, and to the ECB. Monthly and quarterly data are also provided to the IMF under its subscription to the Funds SDDS framework.

\section{Assurances of Integrity}

\section{Integrity of data processes}

65. Budget data are reasonably reliable and the variance between budgeted and actual outturn of main fiscal aggregates is disclosed to the public. $\quad 4.1 .1$ The main factors accounting for this variance are the divergence of key macroeconomic variables from projections used during budget preparation, and expenditure control issues in certain sectors. The federal government usually presents one supplementary budget to parliament before end-April, following a budget control exercise. In some years, additional, targeted supplementary budgets are introduced. The general statement accompanying the April supplementary budget includes a budgetary outlook for the rest of the year. In this outlook any changes to the macro outlook are explained, as well as the government's fiscal or budgetary policy response. The reporting of the regions and communities to their respective parliaments is usually only once in the course of the budget year, also based on a "budget control" in March-April.

\section{Contingency spending is allowed only in extreme and unforeseeable circumstances.

The use of such spending has been curtailed through the budget reforms of 1989. All contingency spending now needs notification to, and ex-post approval by, parliament. Above a certain amount, contingency spending is only allowed if the government 'blocks' other spending lines to the amount being requested on an emergency basis. 
These blocked expenditures can only be carried out again following approval of the special supplementary budget request for the emergency expenditure.

\section{Full statements on accounting policy are not included in the budget and final} accounts documents, but an indication of the relevant legislation is provided. 4.1.2 The budget documentation, budget legislation, and underlying regulations describe the characteristics of the current cash-based budget accounting system. However, the accounting standards are not spelled out as such, and the fact that most agencies affiliated with government use a form of accrual accounting is not evident from the budget documentation. In this cash-based system, revenues are recorded when received in the bank, and expenditures when the payment orders are submitted by line ministry accounting officers ("ordonnateurs") to the Ministry of Finance. In addition to accounting for cash transactions, the budget systems accounts for vested rights on the revenue side and for commitments on the expenditure side. Social security funds and local government already work with a system of (modified) accrual accounting.

\section{The federal government and most communities and regions still share the same underlying accounting system.

Only the Brussels region has introduced double entry bookkeeping based on accrual accounting standards. Application of accounting norms at the regional and community level has begun to deviate from federal government practice. In response to this developments, the new 2003 legislation aims to introduce accrual accounting standards for all governments. A discussion is ongoing to what extent full accrual standards will be introduced at the federal level and in the regions and communities, and indications are that some governments may only introduce a form of modified accrual accounting and not adopt accrual standards for assets and liabilities. While revenues would still be recorded on a time-adjusted cash basis, expenditures will be recorded at the moment of delivery of goods. Such modified accrual system would not record investment on a cost of capital basis, and would thus mirror more closely the ESA 95 reporting norms as already applied for fiscal reporting to the EU on a national accounts basis.

\section{The processes of accounts reconciliation and fiscal reporting are effective at the federal level. \\ 4.1.3 \\ Budget and monetary accounts are reconciled on a regular basis through the Treasury's financial management information system. Decentralized accounts are reconciled on a monthly basis. Reconciliation of budget data with the information maintained by line ministries does not take place systematically.}




\section{Independent oversight}

\section{External audit is fully independent of the executive branch, and its mandate covers all public sector activities with the exception of those at the municipal level.

The role of the Court of Audit as independent financial controller of the executive on behalf of the legislature is established in the Constitution. The Court has powers to scrutinize and request all information it deems necessary on fiscal, accounting and financial operations of the different tiers of government, organizations of public interest, state-owned enterprises established by law, and the provinces. It is independent of the executive and accountable to the legislature, which appoints its members for life; and its budget is determined solely by the House of Representatives. The Court's mandate has been expanded from covering the regularity and legality of expenditure to a more performance-oriented assessment of government finances. In anticipation of legislation that comes into force in 2008, the Court has begun to shift the focus on its activities to ex-post audit. The ultimate effectiveness of the Court is determined by the willingness of the legislature to hold the executive to account, and by its public prestige, which often has had the most direct impact on financial management practices.

\section{The regions and communities need to strengthen their audit capacity. 4.2.1}

The regions and communities continue to face a sizeable backlog of audited final accounts. Indications are that limited financial management capacity in government agencies is the most pressing issue here, and not a lack of support from the Court of Audit. The federal government has managed to speed up the finalization of its accounts in part by deferring such "late reporters" to the final accounts of subsequent years. As part of the gradual reform of the francophone control system, internal audit units are being created which are affiliated with the executive. These internal auditor cells will function as instruments of ministry and agency management, and be concerned mostly with ex-post assessment of the integrity and accuracy of financial management systems as well as the effectiveness, efficiency and value for money of government expenditure.

\section{The legislature discusses external audit reports, but does not systematically follow up on audit findings.

The report of the Court of Audit with the most substantial impact is the one on the budget and budget documentation, which is submitted together with the budget documents to every parliamentarian, and is discussed in the Committee of Finance and Budget of the House of Representatives. The Court also assesses the governments' final accounts, which are discussed by a Committee on Accounts; however, this discussion has limited political impact. All documents of the Court sent to the legislature are publicly available. The Court of Audit reports on the follow-up to its recommendations, but a systematic tracking at the level of the ministries and agencies does not take place. 


\section{External scrutiny of macroeconomic models and assumptions takes place and economic projections are prepared by a relatively independent federal institution.}

The macroeconomic framework underlying the budget is updated semi-annually by the Federal Planning Bureau on behalf of the National Accounts Institute through publication of a document called the Economic Budget. Formally, the Bureau is an autonomous agency with the Minister of Economy and the Prime Minister as delegating authorities, but for this exercise it can act fully independently. It coordinates its forecasts with the research department of the central bank. The Federal Planning Bureau also produces a medium-term macroeconomic and fiscal outlook of the Belgian economy, which is also an important input for the medium-term fiscal scenarios presented by the High Council of Finance. External bodies (the Eurosystem/ESCB, and international organizations such as the OECD, the IMF and the European Commission) provide regular and independent forecasts for the Belgium economy and monitor the country's fiscal policy; as do some commercial banks, the major credit rating agencies, and an economic institute affiliated with the university of Louvain-la-Neuve (IRES). These organizations and institutes also publish selected studies of the forecast methodology used by the government and its forecast record. This provides for adequate discussion and debate in the public realm on the realism and quality of the government's macro forecasts.

\section{The National Accounts Institute (NAI) responsible for providing the ESA 95-} based fiscal data is given legislative assurance of independence.

The NAI is a public entity created in 1994 with a legal mandate to provide national accounts data and forecasts through a collaborative arrangement with the National Bank and the Federal Planning Bureau. The 1962 law on official statistics, as amended in July 2006, safeguards the impartiality and professional independence of the institutions, including the NAI, engaged in the production and dissemination of national accounts data, and other statistics more generally. The NBB prepares and publishes quarterly and annual national accounts data according to the ESA 95 methodology on behalf of the NAI, including for the fiscal sector. The NBB also transmits fiscal data to the European Commission, Eurostat, and the ECB under the acquis communautaire. The Federal Planning Bureau produces Belgium's input-output tables, including the data on government.

\section{IMF STAFF COMMENTARY}

75. Belgium in many areas meets, and in some cases exceeds, the requirements of the fiscal transparency code.

The basic government finance processes are supported by a sound institutional and legal framework, while much progress has been made in recent years to improve the provision of fiscal data and information on taxes and regulations through the internet. In particular, several of the debt management agencies have developed state of the art processes in debt and cash management. Fiscal policy is underpinned by a strong economic forecasting capacity, and an overall successful fiscal coordination mechanism supported by a well-respected advisory council, the High Council of Finance. The audit framework is extensive and provides assurances for the legality, regularity and accuracy of fiscal information. 


\section{Roles and responsibilities in the budget process are clear, with a well-defined separation of powers between the executive and legislature.}

The Court of Audit is independent, but responsive to queries of parliament and it provides essential feedback on the financial management of government. Laws and regulations governing private sector activity are generally transparent, unbiased and harmonized with the acquis communautaire. The Belgium National Bank is part of the independent System of European Central Banks and provides impartial data and research support for fiscal policy coordination. Fiscal policy is assisted by a de facto independent forecasting agency, the Federal Planning Bureau, and by the High Council of Finance. Tax legislation is very complex, but well publicized, and tax payer rights are clearly spelled out.

\section{Fiscal information is provided through regular publications and by extensive use of the internet.}

Fiscal information covers the whole of general government and is aligned with ESA 95 standards. Public debt information is extensive, and includes information on the government's debt management strategy and planned market operations. The tax administration has put most tax legislation and supporting documentation on the internet, including information on rulings. Use of e-government facilities to submit tax returns is increasing rapidly and tax administration is being reformed to be more efficient and client-oriented.

\section{Budget formulation is appropriately supported by medium-term} macroeconomic forecasts and clearly formulated medium-term fiscal policy goals. Short- and medium-term macroeconomic projections and studies on important fiscal issues, such as population aging, are prepared regularly to high quality standards. Fiscal policy is presented clearly, and in a medium-term context, both in the budget documentation and in the yearly updates of Belgium's Stability Program, as submitted to the EU. Parliament has adequate opportunities to scrutinize budget documents and question ministers on budgetary issues. Expenditure data is analyzed and presented in various formats, including according to economic and functional classifications that are aligned with international standards. Parliaments are regularly informed on budget execution, while provisional audited annual accounts of core government activities are made available by May of the following budget year.

\section{Audit processes are extensive and help improve budget management decisions, practices and standards.}

Government financial decisions are evaluated both ex-ante and ex-post, by various institutions. Notably, the Court of Audit provides its comments on the budget documents as well as the final accounts. The National Accounts Institute is given an adequate mandate for providing unbiased fiscal information, while the macroeconomic forecasts of the Federal Planning Bureau are presented in the context of competing publications of international organizations, universities and the financial sector.

\section{Four main areas are seen as priorities for improving overall transparency and strengthening reform efforts.}

These relate to improving the quality and openness of budget processes; increasing the public availability of information with regard to fiscal risks and the financial performance of sub-national tiers of government; strengthening the arrangements for fiscal policy coordination; and better coordinating and simplifying the internal audit processes. In some cases, steps to improve transparency in these areas are already 
under active consideration, and so the following comments are offered to stimulate further discussion and to suggest options for consideration.

\section{Budget processes}

\section{The budget documentation and the budget process provide limited insight in} the concrete objectives and targets of government expenditure.

As a result, it is difficult to ascertain why certain spending takes place and whether resources are used effectively. Budget review processes (within the executive itself) are not focused on issues of policy substance, effectiveness and efficiency, which translates into a very incremental approach to budgeting. In this regard, the Ministry of Budget could consider increasing the performance orientation of the budget process and strengthening its own policy review capacities.

\section{The quality and detail of medium-term budget estimates could be improved} and budgetary decision-making itself be more oriented to the medium-term.

Medium-term expenditure estimates are often policy targets rather than realistic assessments of future expenditure. As described in Box 6, medium-term expenditure targets during budget preparation should be confronted with well-costed estimates of future expenditure. This should be done down to at least the level of budget appropriation. This would allow fiscal policy targets be translated into expenditure decisions, which in turn would facilitate meeting the targets. ${ }^{32}$ The authorities should therefore consider a medium-term budgetary framework to guide the annual budget process. Such a framework would have the added benefit of facilitating the coordination of fiscal and expenditure policies between the federal level and the regions and communities. It also would provide the opportunity for an early decisionmaking round in the budget process on strategic spending priorities.

\section{The budget documents could provide a clearer presentation of new policy measures and their costs over the medium-term.}

In approving new policy and related expenditure, parliaments should be in a position to evaluate the cost of expenditure and tax measures over the medium-term. In particular, entitlement and tax legislation are prone to rise sharply after the initial budget year. Consideration could be given to have the Court of Audit assess the costing of new expenditure and tax measures in the annual budget.

\section{The implementation of fiscal policy at the federal level appears to overly rely on cash controls and one-off expenditure measures.}

A lack of synchronization between commitment and cash controls has resulted in payment arrears. To avoid these problems, governments should control expenditure commitments better during the year, or include a budget reserve in their budget planning (as is already being done successfully by the Brussels Region). Recourse to one-off measures typically lowers the quality of spending and can result in nontransparent claims on future budget resources.

\footnotetext{
32 This recommendation does not imply the approval by parliament of multi-year budgets, just that budgetary decision-making addresses the medium-term fiscal and expenditure targets through annually updated decision-making over the medium-term.
} 


\section{Budget implementation by departments and agencies could be streamlined through less detailed input controls.}

Ongoing reform efforts to ease the control burden on line ministries need to be maintained. The scope for changing budget allocations of line ministries within set limits, and those of the operational units within them, should be expanded and expenditure control for delegated decisions should be carried out at a more aggregate level. Upgrading internal audit capacity and retaining detailed monitoring would provide better assurances for efficient expenditure control.

\section{The accounting framework of the various layers of government should be harmonized and its ability to provide consolidated and balance sheet data improved.}

Core government activities still have a cash-based, single-entry accounting system, while local government and agencies at the various levels of government have introduced a form of accrual accounting. The harmonization of the accounting systems would improve in-year reporting on consolidated government expenditure. The mission would support in first instance aligning accounting standards with ESA 95 reporting requirements. However, ESA 95 does not represent full accrual standards and does not require full financial information on government assets and liabilities. A full accrual accounting framework would support a further modernization of government operations with a view to increasing managerial independence and accountability and focus on operational efficiency. For this reason, the authorities would be well-advised to keep open the option of further development towards full accrual accounting, particularly in the choice of new financial management information systems.

\section{Payment processes could be further strengthened and more effectively monitored at the respective treasuries.}

Federal and regional treasuries lack information on the average lag within line ministries between the receipt of invoices and the dispatch of payment instructions as given by departments. Information on bills payable should be a priority for any new management information system. Functional ministries should adhere to well defined standards for their payment processing responsibilities, and be financially sanctioned for transgressions.

\section{Public availability of information}

\section{The presentation of fiscal risk could be improved in several respects at all levels of government.}

Budget documents should include overviews of all government contingent liabilities, with some analysis of type of risk, sector for which risk is borne, maximum liability, claims paid out, and possible remuneration received; this overview could usefully include information on PPPs. The budget documents should also provide overviews of tax expenditures and their estimated cost in past, present and coming years. Tax expenditures should in essence be regarded and presented as regular expenditure on a multi-year basis. Finally, additional use could be made of scenario analysis with a view to providing insight into the fiscal impact of changes to macroeconomic variables and different policy options. 


\section{The monitoring of in-year budgetary data of local government and agencies needs to be strengthened.}

In-year fiscal data compiled by the National Accounts Institute in part are based on ad hoc estimates of expenditure by agencies and local governments, which weakens the reliability of the overall figures for consolidated general government. More accurate information on agencies and local government could help regions keep better track of intergovernmental transfers and the financial position of local government, in addition to facilitating the monitoring of their own budget.

\section{The timeliness and content of the final accounts should be improved.}

In spite of improvements in recent years, many segments of government continue to provide full and audited final accounts only with considerable delay. This delay raises a serious quality concern regarding the budget process, as it diminishes the control influence of parliament on the executive. Governments at all levels should provide strong incentives to agencies and any other account holders to produce final accounts in a timely fashion. In addition, the content of final accounts could be improved by including more information on the activities and results funded through government expenditures.

\section{Information on the governance of state-owned equity holdings could be made more transparent.}

The budget documents could present an annual overview of government equity holdings, profits retained, board members appointed and their remuneration, and could discuss the objectives and strategy with respect these holdings. The strategic use of government resources might benefit from having state-owned equity managed through a dedicated and professional holding company operating in a clear legal framework and with a clear management contract free of day-to-day political operations.

\section{Roles and responsibilities}

\section{The institutional arrangement for fiscal policy coordination could be} strengthened and the independent role of the High Council of Finance enhanced. Trust and confidence in the High Council of Finance are indispensable for the working of the informal agreement on fiscal targets. The role of the High Council of Finance could be reinforced and expanded through additional institutional safeguards as to its continuity and independence and through a mandate that covers all important policies bearing on the fiscal costs of an aging population, including - in consultation with the High Employment Council-aging-related aspects of social security and labor market reform. Consideration could also be given to have the borrowing requirements section of the Council present its regular reports to the different parliaments, which would enhance the stature of the Council. The budget agreements concluded in the Comite de Concertation could be turned into formal internal stability pacts, which would specify all quantitative targets and spell out the underlying expenditure and revenue measures and which would be communicated to the respective assemblies and be published.

\section{Integration of financial information}

\section{Internal audit processes could be better coordinated and simplified.}

Belgium maintains a considerable number of internal control and audit layers. The shift of orientation of the Court of Audit to ex-post assessment and more performance 
evaluation work is a very welcome development in this regard. The Internal Audit Units being developed are also a very important new tool for improving the effectiveness and dependability of government financial processes. Given the many layers of control and audit activities, the Court of Audit's recent Single Audit initiative to minimize overlap, coordinate work programs, and share common data and analysis is particularly timely. Over the medium-term, further reform of the overall audit framework may require clarifying and spelling out the complementary roles of Inspectors of Finance and the new internal control and audit services. 


\section{Appendix I. A Summary Assessment of Practices}

[COMPLETE ONLY AFTER REVIEW—USING AGREED SUMMARY ASSESSMENTS FROM TEXT]

\begin{tabular}{|c|c|c|}
\hline $\begin{array}{c}\text { Code } \\
\text { Reference }\end{array}$ & Summary Assessment & Comment \\
\hline \multicolumn{3}{|c|}{ Clarity of roles and responsibilities } \\
\hline 1.1 .1 & General government is defined consistently with GFS and ESA 95 principles. & \\
\hline 1.1.2. & $\begin{array}{l}\text { The fiscal roles of the executive, legislative, and judicial branches, and those of } \\
\text { different levels of government are clearly defined. }\end{array}$ & \\
\hline 1.1 .3 . & $\begin{array}{l}\text { Mechanisms for the coordination and management of budgetary and extrabudgetary } \\
\text { activities are well specified but also complicated. }\end{array}$ & \\
\hline 1.1 .4 . & $\begin{array}{l}\text { The NBB is fully independent and its role in fiscal matters is purely advisory. Public } \\
\text { nonfinancial and financial corporations operate at arms length from the government, } \\
\text { the ownership position of which is not transparently reported. }\end{array}$ & \\
\hline 1.1 .5 . & $\begin{array}{l}\text { Government regulation of the private sector is being simplified, but remains } \\
\text { burdensome. }\end{array}$ & \\
\hline 1.2 .1 & $\begin{array}{l}\text { The legal framework for management of public funds is both complex and } \\
\text { comprehensive. }\end{array}$ & \\
\hline 1.2 .2 & $\begin{array}{l}\text { The legal framework governing taxation and tax administration is transparent, and } \\
\text { taxpayers' rights and obligations are clearly defined. }\end{array}$ & \\
\hline 1.2.3. & $\begin{array}{l}\text { There is no comprehensive code of behavior for civil servants, but elements are } \\
\text { covered by various laws and statements. }\end{array}$ & \\
\hline 2.1 .1 & $\begin{array}{l}\text { The federal budget documents cover central government activities comprehensively, } \\
\text { and provide summary data on general government. }\end{array}$ & \\
\hline 2.1 .2 . & $\begin{array}{l}\text { The federal budget documentation discloses the main fiscal aggregates for two years } \\
\text { prior and three years beyond the budget year. }\end{array}$ & \\
\hline 2.1 .3 . & $\begin{array}{l}\text { There is no systematic and comprehensive reporting of contingent liabilities and } \\
\text { quasi-fiscal activities in the budget; statements on tax expenditures are published ex- } \\
\text { post and with a long delay. }\end{array}$ & \\
\hline 2.1 .4$. & Comprehensive information on debt and financial liabilities is provided. & \\
\hline
\end{tabular}




\begin{tabular}{|c|c|c|}
\hline \multicolumn{3}{|c|}{ Public availability of information } \\
\hline 2.1.5. & $\begin{array}{l}\text { The combined fiscal position of communities and regions and the consolidated fiscal } \\
\text { balance of the whole of government are published. }\end{array}$ & \\
\hline 2.2.1. & Regular publication of fiscal data is a legal requirement. & \\
\hline 2.2.2. & $\begin{array}{l}\text { Advance release data are announced for the fiscal data published by the federal } \\
\text { government. }\end{array}$ & \\
\hline \multicolumn{3}{|c|}{ Open budget preparation, execution, and reporting } \\
\hline 3.1 .1$. & $\begin{array}{l}\text { The budget documents include a statement on medium-term policy objectives and an } \\
\text { analysis of fiscal sustainability issues. }\end{array}$ & \\
\hline 3.1 .2 . & $\begin{array}{l}\text { Clearly defined numerical targets for the overall balance of general government and } \\
\text { the balances of federal government, communities and regions anchor the budget } \\
\text { process. }\end{array}$ & \\
\hline 3.1 .3 & Budget forecasts and underlying macroeconomic assumptions are clearly presented. & \\
\hline 3.1 .4 . & $\begin{array}{l}\text { The budget documents not always clearly distinguish the costs of new initiatives } \\
\text { from those of ongoing projects. }\end{array}$ & \\
\hline 3.1 .5 . & $\begin{array}{l}\text { The budget assesses the sensitivity of estimates to changes in economic variables and } \\
\text { discusses fiscal risks. }\end{array}$ & \\
\hline 3.2 .1 . & $\begin{array}{l}\text { The presentation of the main budget estimates is broadly consistent with international } \\
\text { standards. }\end{array}$ & \\
\hline 3.2 .2 . & $\begin{array}{l}\text { The budget documents present the objectives and expected results from government } \\
\text { activities. }\end{array}$ & \\
\hline 3.2.3. & $\begin{array}{l}\text { The overall balance ("net borrowing/lending") of general government is regularly } \\
\text { reported. }\end{array}$ & \\
\hline 3.3.1. & $\begin{array}{l}\text { The accounting systems are overall capable of producing accurate in-year reports, } \\
\text { but the lack of a single accounting standard within and between governments } \\
\text { complicates budget tracking and reporting. }\end{array}$ & \\
\hline 3.3 .2 . & $\begin{array}{l}\text { Procurement rules and practices are transparent, publicly available and in accordance } \\
\text { with the acquis communautaire; civil service employment procedures are clear and } \\
\text { well-publicized. }\end{array}$ & \\
\hline 3.3.3. & $\begin{array}{l}\text { Internal control and audit systems could be made more effective, less resource- } \\
\text { intensive, and less focused on legality; monitoring of invoices, payment patterns, and } \\
\text { the use of accounts need to be strengthened. }\end{array}$ & $\begin{array}{l}\text { Internal control and audit } \\
\text { mechanisms are being modernized, } \\
\text { including through a reform of their } \\
\text { legal framework. }\end{array}$ \\
\hline
\end{tabular}




\begin{tabular}{|l|l|l|}
\hline 3.3 .4$. & $\begin{array}{l}\text { Tax administration has effective internal control and monitoring mechanisms, and its } \\
\text { independence is legally protected. }\end{array}$ & $\begin{array}{l}\text { The legislature twice a year receives detailed in-year reports on the budget outturn, } \\
\text { and undertakes an extensive interim budget review in the spring. }\end{array}$ \\
\hline 3.4 .1$. & Audit reports are available on a timely basis for the federal government only. & $\begin{array}{l}\text { Efforts are ongoing in communities } \\
\text { and regions to reduce the delays. }\end{array}$ \\
\hline 3.4 .2$. & $\begin{array}{l}\text { The budget documents present a general overview of the objectives and expected } \\
\text { results from government activities. }\end{array}$ & \\
\hline 3.4 .3$. & $\begin{array}{l}\text { Budget data are a reasonably reliable indicator of revenue and expenditure trends and } \\
\text { reflect new policies. }\end{array}$ & \\
\hline Assurances of integrity & $\begin{array}{l}\text { The budget and final account documents do not include a full statement on } \\
\text { accounting policies, but make reference to the relevant legislation. }\end{array}$ & \\
\hline 4.1 .1$. & The processes of accounts reconciliation and fiscal reporting are overall effective. & \\
\hline 4.1 .2$. & $\begin{array}{l}\text { External audit is fully independent of the executive branch and its mandate covers all } \\
\text { public sector activities other than those at the municipal level. }\end{array}$ & \\
\hline 4.1 .3$. & $\begin{array}{l}\text { Macroeconomic models and assumptions are externally scrutinized, and economic } \\
\text { projections are prepared by a relatively independent federal institution. }\end{array}$ & \\
\hline 4.2 .1$. & $\begin{array}{l}\text { The institutions preparing fiscal data in national accounts format are given legal } \\
\text { assurance of independence. }\end{array}$ \\
\hline 4.2 .2$. &
\end{tabular}


Appendix II. Public Availability of Information-A Summary

\begin{tabular}{|c|c|c|c|c|c|}
\hline & $\begin{array}{c}\text { Budget and fiscal report } \\
\text { element }\end{array}$ & $\begin{array}{c}\text { Included in budget/report } \\
\text { documents }\end{array}$ & Available to the public & Para. ref. & Code ref. \\
\hline 1. & $\begin{array}{l}\text { Central government }(\mathrm{CG}) \\
\text { budget estimates }\end{array}$ & - Budget documents & $\begin{array}{l}\frac{\text { www.dekamer.be }}{\text { www.lachambre.be }} \\
\text { www.begroting.be } \\
\text { www.budgetfederal.be }\end{array}$ & & 2.1 .1 \\
\hline 2. & CG Defense Expenditures & $\begin{array}{l}\text { - Budget documents } \\
\text { - Annual report of the "Base } \\
\text { Documentaire Générale" } \\
\text { - Government expenditure by } \\
\text { function (COFOG) }\end{array}$ & $\begin{array}{l}\frac{\text { www.dekamer.be }}{\text { www.lachambre.be }} \\
\text { www.begroting.be } \\
\text { www.budgetfederal.be } \\
\text { www.nbb.be }\end{array}$ & & 2.1 .1 \\
\hline 3. & $\begin{array}{l}\text { CG EBFs (including special } \\
\text { development funds, social } \\
\text { security funds, resource revenue } \\
\text { funds) }\end{array}$ & - Budget documents & $\begin{array}{l}\text { www.dekamer.be } \\
\text { www.lachambre.be }\end{array}$ & & 2.1 .1 \\
\hline 4. & CG Budget outturns & $\begin{array}{l}\text { - Yearly Report of the NBBN } \\
\text { (February) } \\
\text { - NAI government accounts } \\
\text { - Report of the High Council of } \\
\text { Finance } \\
\text { - Vademecum on financial and } \\
\text { statistical information on the social } \\
\text { protection in Belgium }\end{array}$ & $\begin{array}{l}\text { www.nbb.be } \\
\text { www.nbb.be (belgostat) } \\
\text { www.docufin.fgov.be } \\
\text { www.socialsecurity.fgov.be }\end{array}$ & & 2.1 .2 \\
\hline 5. & CG Budget forecasts & $\begin{array}{l}\text { - Budget documents for current year, } \\
\text { mid-term objectives in Stability } \\
\text { program } \\
\text { - } 2 \text { year forecast in the Economic }\end{array}$ & $\begin{array}{l}\text { www.docufin.fgov.be } \\
\underline{\text { www.budgetfederal.be }}\end{array}$ & & 2.1.2 \\
\hline
\end{tabular}




\begin{tabular}{|c|c|c|c|c|c|}
\hline & $\begin{array}{c}\text { Budget and fiscal report } \\
\text { element }\end{array}$ & $\begin{array}{c}\text { Included in budget/report } \\
\text { documents }\end{array}$ & Available to the public & Para. ref. & Code ref. \\
\hline & & $\begin{array}{l}\text { Reviews of the NBBN } \\
\text { - Economic Outlook of the Federal } \\
\text { Planning bureau ( } 5 \text { year outlook) }\end{array}$ & $\begin{array}{l}\text { www.nbb.be } \\
\text { www.plan.be } \\
\end{array}$ & & \\
\hline 6. & CG Contingent liabilities & - Not available & & & 2.1 .3 \\
\hline 7. & CG Tax Expenditures & $\begin{array}{l}\text { - Annex to Budget Documents } \\
\text { (includes estimates of costs for } \\
\text { nearly all taxes) }\end{array}$ & $\begin{array}{l}\text { www.dekamer.be } \\
\underline{\text { www.lachambre.be }}\end{array}$ & & 2.1 .3 \\
\hline 8. & CG QFAs & - Not relevant for Belgium & & & 2.1 .3 \\
\hline
\end{tabular}

\begin{tabular}{|c|c|c|c|c|c|}
\hline & Budget and Fiscal report element & $\begin{array}{c}\text { Included in budget/report } \\
\text { documents }\end{array}$ & Available to the public & Para. ref. & Code ref. \\
\hline 9. & Macroeconomic assumptions & $\begin{array}{l}\text { - Economic Budget of the } \\
\text { Federal Planning Bureau on } \\
\text { behalf of the National } \\
\text { Accounts Institute } \\
\text { - Budget Documents }\end{array}$ & $\begin{array}{l}\text { www.plan.be } \\
\text { www.dekamer.be } \\
\text { www.lachambre.be }\end{array}$ & & 3.1 .3 \\
\hline 10. & $\begin{array}{l}\text { Analysis of fiscal risks/sensitivity } \\
\text { analysis }\end{array}$ & - Not available & & & 3.1 .5 \\
\hline 11. & CG Debt & $\begin{array}{l}\text { - Budget Documents } \\
\text { - Financial Accounts published } \\
\text { by the NBBN } \\
\text { - Annual report of the debt } \\
\text { agency }\end{array}$ & $\begin{array}{l}\text { www.dekamer.be } \\
\text { www.lachambre.be } \\
\text { www.nbb.be (belgostat) } \\
\text { www.debtagency.be }\end{array}$ & & 2.1 .4 \\
\hline 12. & CG Financial Assets & $\begin{array}{l}\text { - Financial Accounts published } \\
\text { by the NBBN }\end{array}$ & www.nbb.be (belgostat) & & 2.1 .4 \\
\hline
\end{tabular}




\begin{tabular}{|c|c|c|c|c|}
\hline 13. & Sustainability Analysis & $\begin{array}{l}\text { - Yearly Report of the Study } \\
\text { Group on Population Aging of } \\
\text { the High Finance Council } \\
\text { - Yearly Report of the section } \\
\text { "Public Sector Borrowing of } \\
\text { the High Finance Council }\end{array}$ & $\underline{\text { www.docufin.fgov.be }}$ & 3.1 .1 \\
\hline 14. & General government budget estimates & $\begin{array}{l}\text { - Budget Report, objectives in } \\
\text { Stability program } \\
\text { - Economic Review (June and } \\
\text { December) of the NBBN } \\
\text { - Economic Outlook of the } \\
\text { Federal Planning Bureau }\end{array}$ & $\begin{array}{l}\frac{\text { www.dekamer.be }}{\text { www.lachambre.be }} \\
\text { www.nbb.be } \\
\text { www.plan.be }\end{array}$ & 2.1 .5 \\
\hline 15. & $\begin{array}{l}\text { CG Monthly/quarterly reports on } \\
\text { fiscal outturn }\end{array}$ & $\begin{array}{l}\text { - Monthly central government } \\
\text { receipts }\end{array}$ & $\underline{\text { www.nbb.be (belgostat) }}$ & 3.4 .1 \\
\hline
\end{tabular}

\begin{tabular}{|c|c|c|c|c|c|}
\hline & Budget and Fiscal report element & Included in budget/report documents & $\begin{array}{c}\text { Available to } \\
\text { the public }\end{array}$ & Para. ref. & Code ref. \\
\hline 16. & $\begin{array}{l}\text { General government Monthly/quarterly } \\
\text { reports on fiscal outturn }\end{array}$ & $\begin{array}{l}\text { Quarterly general governments accounts } \\
\text { published by the NAI } 120 \text { days after the end } \\
\text { of the quarter }\end{array}$ & - (bww.nbb.be & & 3.4 .1 \\
\hline 17. & CG Final Accounts & $\begin{array}{l}\text { Complete Government Accounts published } \\
\text { by the NAI } 9 \text { months after the end of the } \\
\text { year. }\end{array}$ & - & & 3.4 .2 \\
\hline 18. & $\begin{array}{l}\text { Consolidated general government Final } \\
\text { Accounts }\end{array}$ & $\begin{array}{l}\text { - Complete Government Accounts published } \\
\text { by the NAI } 9 \text { months after the end of the } \\
\text { year. }\end{array}$ & $\frac{- \text { www.nbb.be }}{\text { (belgostat) }}$ & & 3.4 .2 \\
\hline
\end{tabular}

